\title{
Hyperglycemic Stress and Carbon Stress in Diabetic Glucotoxicity
}

\author{
Xiaoting Luo ${ }^{1,2}$, Jinzi Wu1, Siqun Jing1,3, Liang-Jun Yan',* \\ ${ }^{1}$ Department of Pharmaceutical Sciences, UNT System College of Pharmacy, University of North Texas Health \\ Science Center, Fort Worth, TX 76107, USA \\ ${ }^{2}$ Department of Biochemistry and Molecular Biology, Gannan Medical University, Ganzhou, Jiangxi province, \\ China, 341000 \\ ${ }^{3}$ College of Life Sciences and Technology, Xinjiang University, Urumqi, Xinjiang, China, 830046
}

[Received May 3, 2015; Revised July 1, 2015; Accepted July 2, 2015]

\begin{abstract}
Diabetes and its complications are caused by chronic glucotoxicity driven by persistent hyperglycemia. In this article, we review the mechanisms of diabetic glucotoxicity by focusing mainly on hyperglycemic stress and carbon stress. Mechanisms of hyperglycemic stress include reductive stress or pseudohypoxic stress caused by redox imbalance between $\mathrm{NADH}$ and $\mathrm{NAD}^{+}$driven by activation of both the polyol pathway and poly ADP ribose polymerase; the hexosamine pathway; the advanced glycation end products pathway; the protein kinase $\mathrm{C}$ activation pathway; and the enediol formation pathway. Mechanisms of carbon stress include excess production of acetyl-CoA that can over-acetylate a proteome and excess production of fumarate that can over-succinate a proteome; both of which can increase glucotoxicity in diabetes. For hyperglycemia stress, we also discuss the possible role of mitochondrial complex I in diabetes as this complex, in charge of $\mathrm{NAD}^{+}$regeneration, can make more reactive oxygen species (ROS) in the presence of excess NADH. For carbon stress, we also discuss the role of sirtuins in diabetes as they are deacetylases that can reverse protein acetylation thereby attenuating diabetic glucotoxicity and improving glucose metabolism. It is our belief that targeting some of the stress pathways discussed in this article may provide new therapeutic strategies for treatment of diabetes and its complications.
\end{abstract}

Key words: glucotoxicity, carbon stress, diabetes, hyperglycemic stress, reactive oxygen species, redox imbalance, pseudohypoxia

\section{Introduction}

Diabetes and its complications are diseases originated from impaired glucose metabolism [1-8]. As glucose metabolism is tightly regulated by insulin, aberrant glucose metabolism can also be regarded as the problems of insulin resistance or insulin deficiency [9-13]. In type 1 diabetes, there is an absolute deficiency or lack of insulin due to $\beta$ cell destruction [14-16]. But in type 2 diabetes, it is more of an insulin resistance problem, at least at the early stage of the disease [11, 17-20]. As hyperglycemia persists, $\beta$ cells attempt to secret more insulin to bring down the blood glucose levels [21]. This compensatory mechanism usually can't last long before eventual exhaustion of $\beta$ cells as $\beta$ cells cannot keep up with the ever increasing demand imposed by a persistent level of chronic hyperglycemia [22-24]. At this stage, insulin deficiency kicks in because of impaired $\beta$ cell function, leading to frank type 2 diabetes $[10,21,25$, 26].

Regardless of which type of diabetes, the apparent manifestation of the disease is a high level of blood 
glucose $[15,27,28]$. While many pathways are activated or upregulated to dispose excess glucose, there is a price that the body has to pay, which is deterioration of cell or organ function caused by the toxicity of persistent hyperglycemia [2, 20, 29-32]. This glucose toxicity, often referred to as glucotoxicity, is mediated by many aberrant glucose metabolic pathways or signaling pathways that can eventually lead to cell death [33-36]. In this review article, we summarize these pathways that can be collectively placed under the umbrella of hyperglycemic stress or carbon stress. For hyperglycemic stress, after a brief overview of physiology and pathophysiology of insulin-mediated glucose metabolism, we discuss those stress pathways (Fig. 1) including the polyol pathway that contributes to reductive stress [36], the protein kinase $\mathrm{C}$ activation pathway, the hexosamine pathway, the advanced glycation end products (AGEs) pathway, and the enediol pathway that all culminate on oxidative stress [36, 37]. For carbon stress, we first discuss the sources and fates of acetyl-CoA and then expand on protein acetylation and succination $[38,39]$ that are mainly caused by the elevated levels of acetyl-CoA [40] fueled by increased utilization of fatty acids in diabetes [41]. It is our belief that understanding the mechanisms of hyperglycemic stress and carbon stress may help identify targets for controlling blood glucose levels and thus would benefit for combating diabetes.

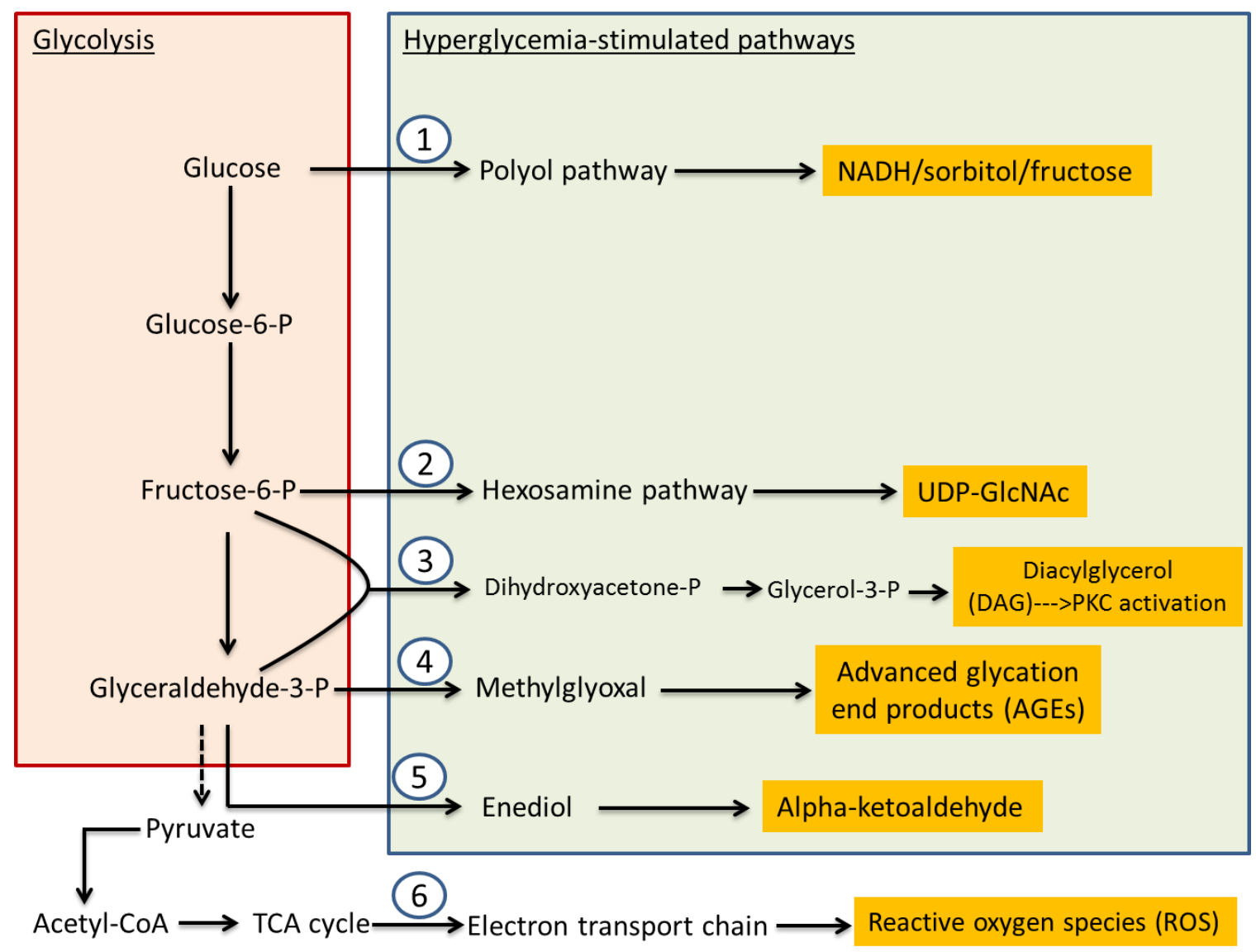

Figure 1. Major pathways upregulated by chronic hyperglycemia. These pathways include the polyol pathway, the hexosamine pathway, PKC activation, formation of advanced glycation end products (AGEs), and the enediol formation pathway. These pathways usually remain dormant under euglycemia conditions whereby majority of the body's glucose is combusted through glycolysis and TCA cycle. 


\section{Physiology and pathophysiology of insulin-mediated glucose metabolism}

The process of glucose extraction from food is achieved in the gastrointestinal tract [42]. This is followed by release of glucose into the blood stream and glucose stimulation of $\beta$ cell insulin secretion that promotes uptake of glucose by muscle and adipose tissues [43]. Any surplus glucose will be stored in the form of glycogen in the liver and skeletal muscle, and in the form of fat in adipose tissue (Fig. 2) [43, 44]. Insulin secretion and high level of blood glucose will also suppress gluconeogenesis in the liver, a process that is impaired in diabetes [44-46]. In type 2 diabetes, both muscle and adipose tissues can be insulin resistant, and will not take up more glucose like they do postprandially under euglycemic conditions [44, 47-49]. Interestingly, this phenomenon of resistance has been suggested to be a defense mechanism to prevent glucose toxicity to these tissues [50]. Indeed, diabetic complications in muscle and adipose tissues are very rare [50]. But the inability of these tissues, in particular, muscle, to take up more glucose, is the fundamental problem of glucotoxicity to other organs such as the brain, the kidney, and the lower limbs [51-54].

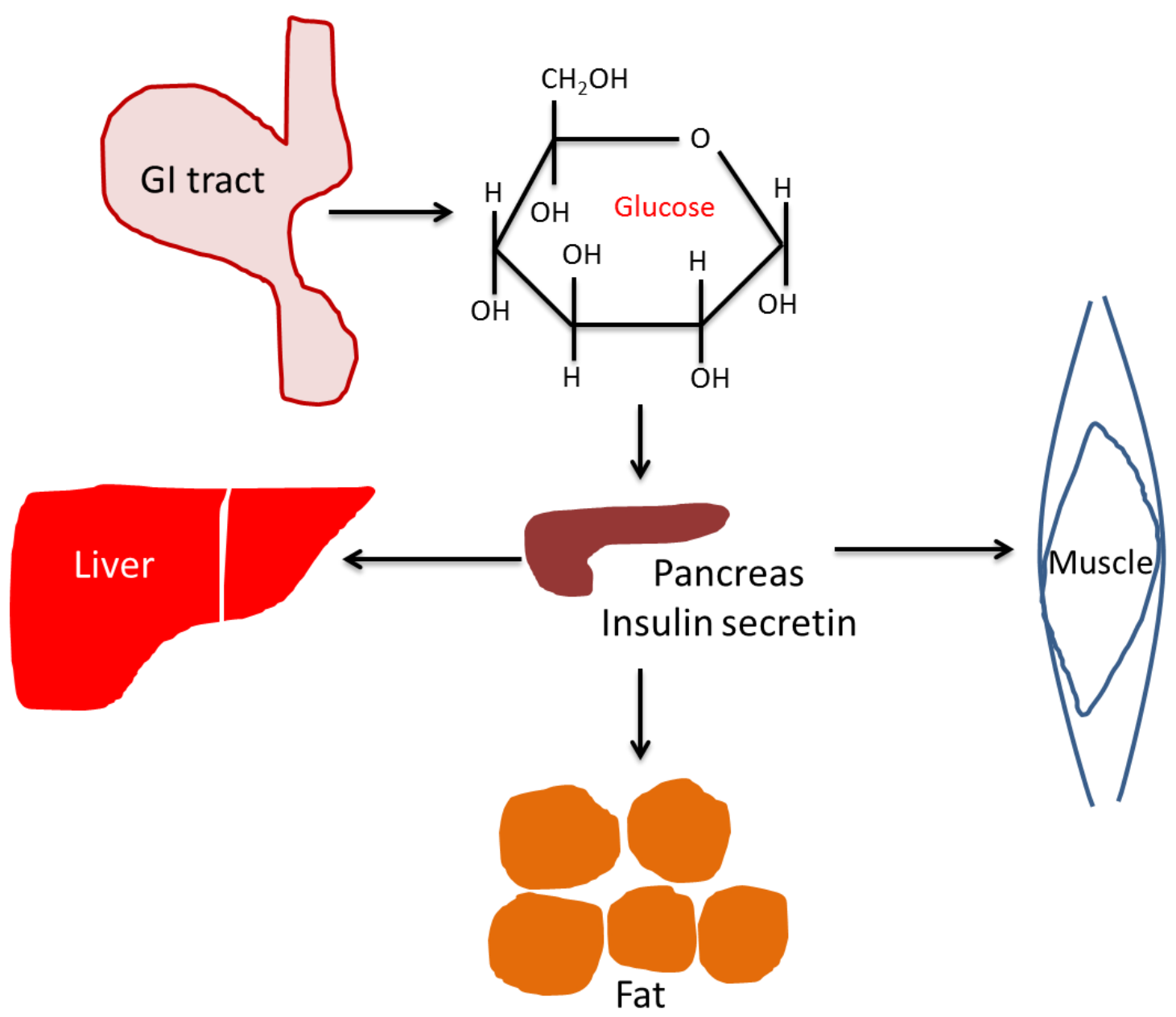

Figure 2. Regulation of glucose homeostasis and pathophysiology of hyperglycemia. Glucose is extracted from food stuff in the gastrointestinal tract and is then released to the blood stream. High level of blood glucose stimulates insulin secretion from islet $\beta$ cell in the pancreas, leading to uptake of glucose by muscle and adipose tissues. Insulin also suppresses the gluconeogenesis in the liver. Excess glucose is stored in the liver and the muscle as glycogen, and in the adipose tissue as fat. This glucose uptake and storage process and the overall control of glucose homeostasis are impaired in diabetes. 
As mentioned above, insulin is tightly linked to glucose metabolism in the body [55-57]. Under normal physiological conditions, insulin stimulates numerous metabolic processes. As shown in Fig. 3, insulin triggers uptake of glucose by muscle and adipose tissue, stimulates fatty acid synthesis from acetyl-CoA, increases the activity of $\mathrm{Na}^{+} / \mathrm{K}^{+}$pumps in muscle cells and adipocytes, and promotes glycogen synthesis in muscle and liver [58]. Insulin also promotes gene expression, protein synthesis, and amino acid uptake in all types of cells [58]. However, all these processes are perturbed in diabetes, leading to progressive glucotoxicity [2, 20, 37, 59] that includes hyperglycemic stress and carbon stress as is to be discussed in the following sections.
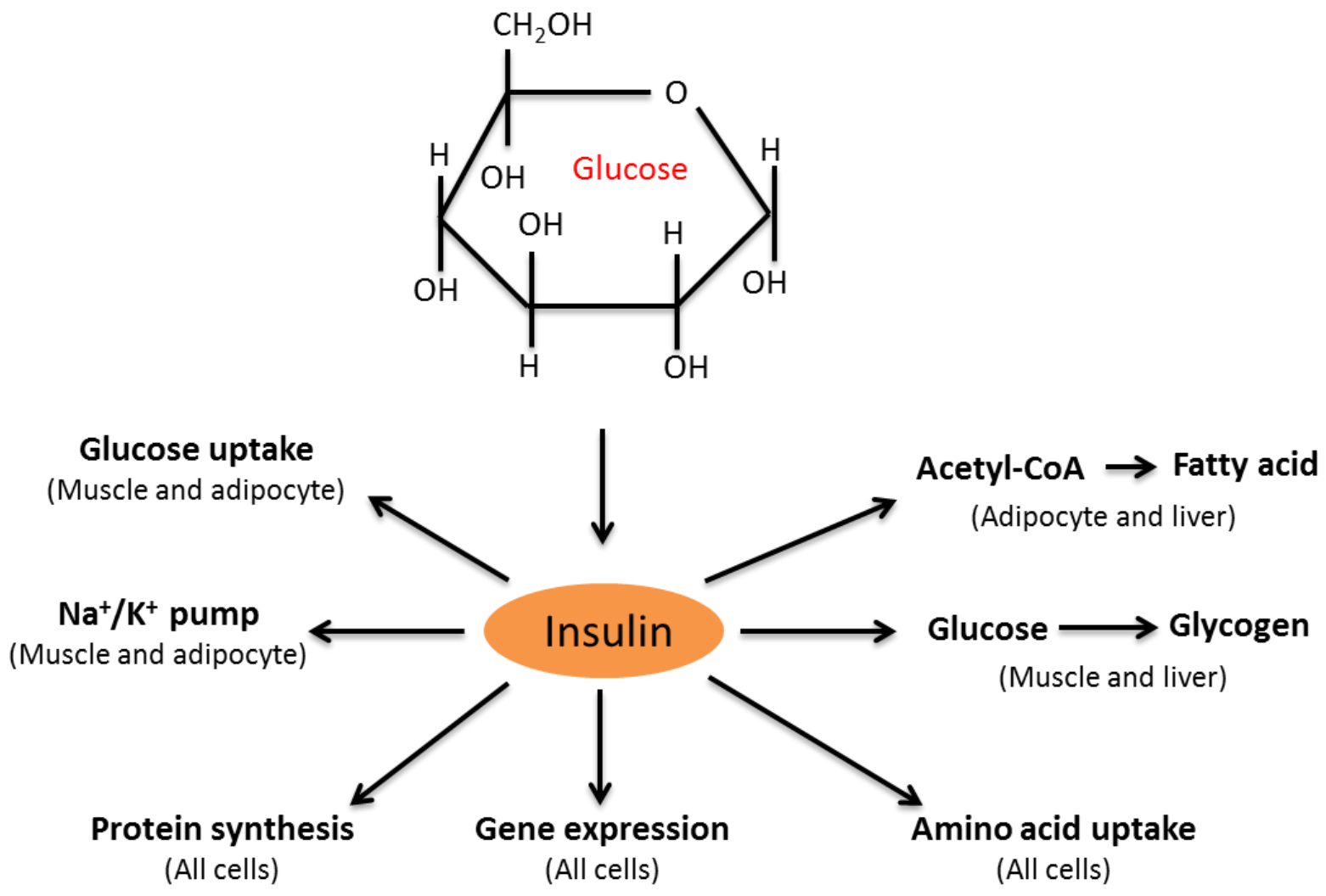

Figure 3. Summary of insulin-stimulated biological processes. Hyperglycemia-induced secretion of insulin can mediate numerous biological processes such as glucose uptake, activation of $\mathrm{Na}^{+} / \mathrm{K}^{+}$pumps, synthesis of fatty acid from acetyl-CoA and glycogen from glucose, amino acid uptake, gene expression, and protein synthesis. Figure adapted from reference [58].

\section{A. Hyperglycemic stress}

A PubMed search indicates that the concept of "hyperglycemic stress" was first noted in diabetes in 1964 [60]. However, a further search for both "hyperglycemic stress" and "glucotoxicity" returned a zero result, demonstrating that a link between glucotoxicity and hyperglycemic stress has not been clearly and firmly established. Herein, we define hyperglycemic stress as one that mainly encompasses the pathways shown in Fig. 1 that all can be attributed to chronic hyperglycemia in diabetes. The mechanisms of 
these stresses are all related to elevated levels of ROS production and oxidative stress [37] and hence these stress pathways are highly interrelated.

\section{Reductive stress}

Reductive stress is defined as excess reducing equivalent in a cell and is usually expressed as an increased ratio between NADH and $\mathrm{NAD}^{+}$(or NADPH and $\mathrm{NADP}^{+}$) [36, 61-65]. In chronic hyperglycemic situation, aldose reductase (AR), catalyzing the first reaction in the polyol pathway, is activated [66-69]. AR has a low affinity to glucose and hence is only active at high levels of glucose [54]. AR catalyzes reduction of glucose to sorbitol that is further oxidized to fructose by sorbitol dehydrogenase (the second reaction of the polyol pathway). As shown in Fig. 4, NADPH is consumed and NADH is produced, with accumulation of sorbitol and fructose that can affect cellular osmosis [70, 71]. While the activity of polyol pathway is usually negligible under euglycemic condition, it has been estimated that at least $30 \%$ of the body's glucose pool is disposed by this pathway under chronic hyperglycemic conditions [72]. Therefore, $\mathrm{NADH}$ level is highly elevated, leading to increased reducing equivalent reflected by an increased ratio between $\mathrm{NADH}$ and $\mathrm{NAD}^{+}$. As $\mathrm{NAD}^{+}$level goes lower, cells undergo pseudohypoxia challenges [73-75].

Pseudohypoxia is different from hypoxia in that the former has low levels of $\mathrm{NAD}^{+}$in the presence of normal level of tissue oxygen [76, 77] while the latter experiences a lower level of tissue oxygen [78-80]. Regardless, both hypoxia and pseudohypoxia will be manifested by impaired NADH oxidation or impaired $\mathrm{NAD}^{+}$regeneration. In this sense, pseudohypoxic stress is equivalent to reductive stress as both are caused by a net decrease in the content of $\mathrm{NAD}^{+}[36,74]$, a central molecule involved in metabolism, signal transduction, and stress response [81-84].
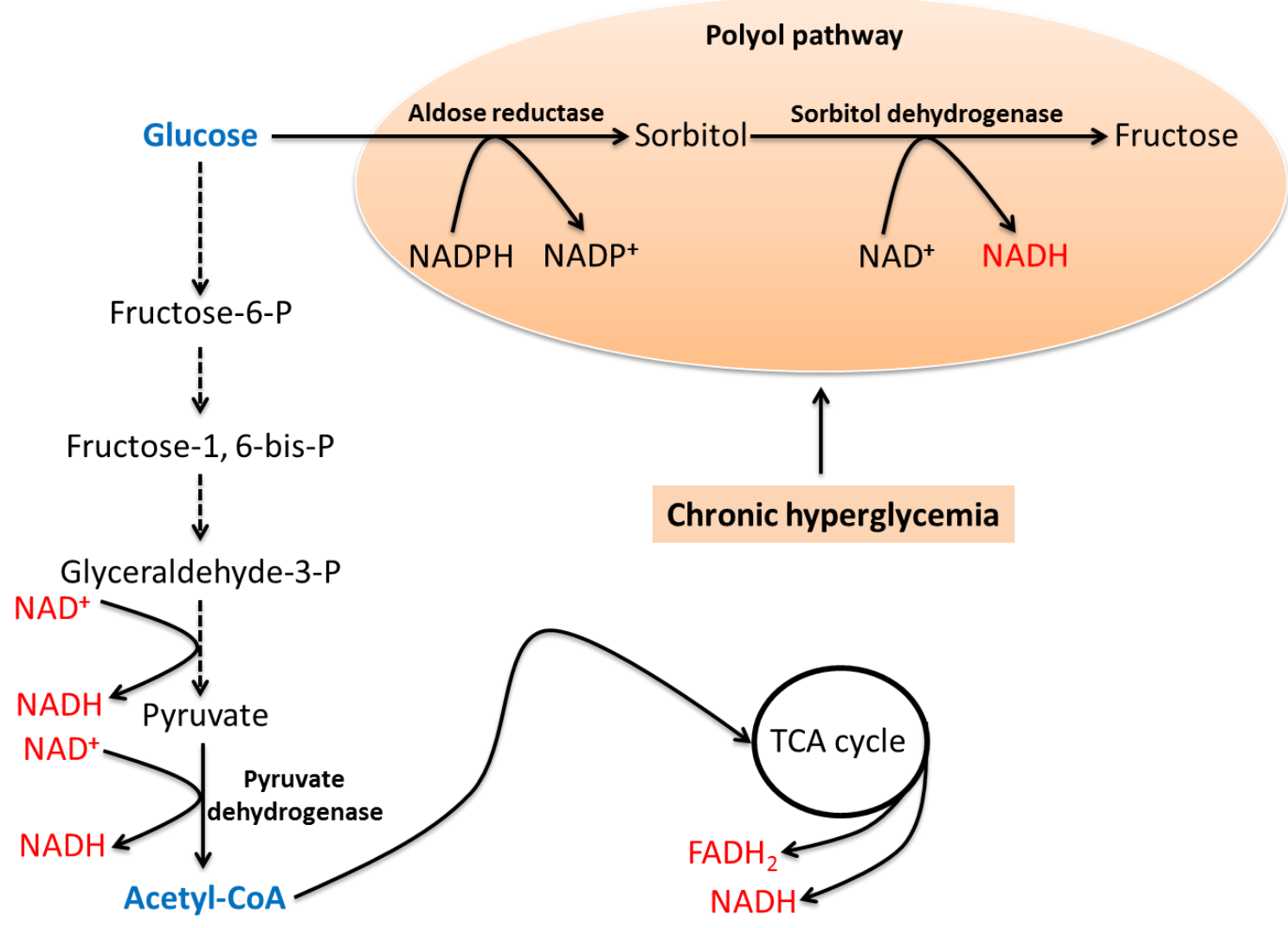

Figure 4. Glucose disposal via the polyol pathway under chronic hyperglycemic conditions in diabetes. This pathway includes two-step reactions. The first one is glucose reduction by aldose reductase to form sorbitol; while the second reaction is sorbitol oxidation by sorbitol dehydrogenase to form fructose. Reducing equivalent is transferred from NADPH to NADH, leading to elevated level of NADH and reductive stress. The glycolytic pathway is also shown. 
Does activation of the polyol pathway lead to depletion of NADPH (the first reaction) in diabetes? This has been repeatedly discussed in the literature and it has been assumed in certain studies that the level of NADPH goes lower in diabetes [85-87], which can diminish GSH content as GSH synthesis requires NADPH $[88,89]$. This assumption probably needs to be examined in a tissue dependent manner as it has been reported that in the lens of diabetic rats, NADPH level was not decreased [90]. Moreover, it has been reported that the pentose phosphate pathway that makes NADPH is also upregulated by chronic hyperglycemia [91, 92], leading to a net transfer of excess reducing equivalent from NADPH to NADH [93]. Indeed, it has been demonstrated that NADPH depleted by the polyol pathway can be quickly replenished by the pentose phosphate pathway [64] and potentially by other pathways as well [94]. Therefore, the pentose phosphate pathway in diabetes could also contribute to reductive stress. Hence, reductive stress may be attributed to both the polyol pathway and the pentose phosphate pathway that are activated or upregulated by hyperglycemia in diabetes.

Additionally, as the second reaction of the polyol pathway consumes $\mathrm{NAD}^{+}$, the polyol pathway can compete for $\mathrm{NAD}^{+}$with glyceraldehyde 3-phosphate dehydrogenase (GAPDH) [95], potentially downregulating the glycolytic pathway. This competition, together with the fact that excess NADH will also inhibit GAPDH [67, 96, 97], can lead to more glucose being diverted to the non-conventional pathways as shown in Fig. 1, thereby aggravating glucotoxicity. Given the detrimental effects of the polyol pathway in diabetes, inhibition or disruption of this pathway has been demonstrated to ameliorate diabetes and its complications [98-100].

While there is an oversupply of NADH in diabetes due to persistent hyperglycemia and enhanced fatty acid $\beta$ oxidation [101-104], there is also likelihood that $\mathrm{NAD}^{+}$ could be depleted. This is due to the activation of poly ADP ribose polymerase (PARP) by oxidative DNA damage during oxidative stress [105-108]. PARP uses $\mathrm{NAD}^{+}$as its substrate and is a nuclear enzyme responsible for DNA repair after damage [109-111]. However, this enzyme, when over-activated, can deplete $\mathrm{NAD}^{+}$, which is often the case in diabetes $[105,112$, 113]. Hence PARP activation has been demonstrated to be involved in cell death [114-117]. That over-activation of PARP contributes to the pathogenesis of diabetes has been further supported by evidence that PRAP knockout or deficient animals are protected from chemical-induced diabetes [118-120] and that PARP inhibitors prevent development of diabetes and its complications [121125].

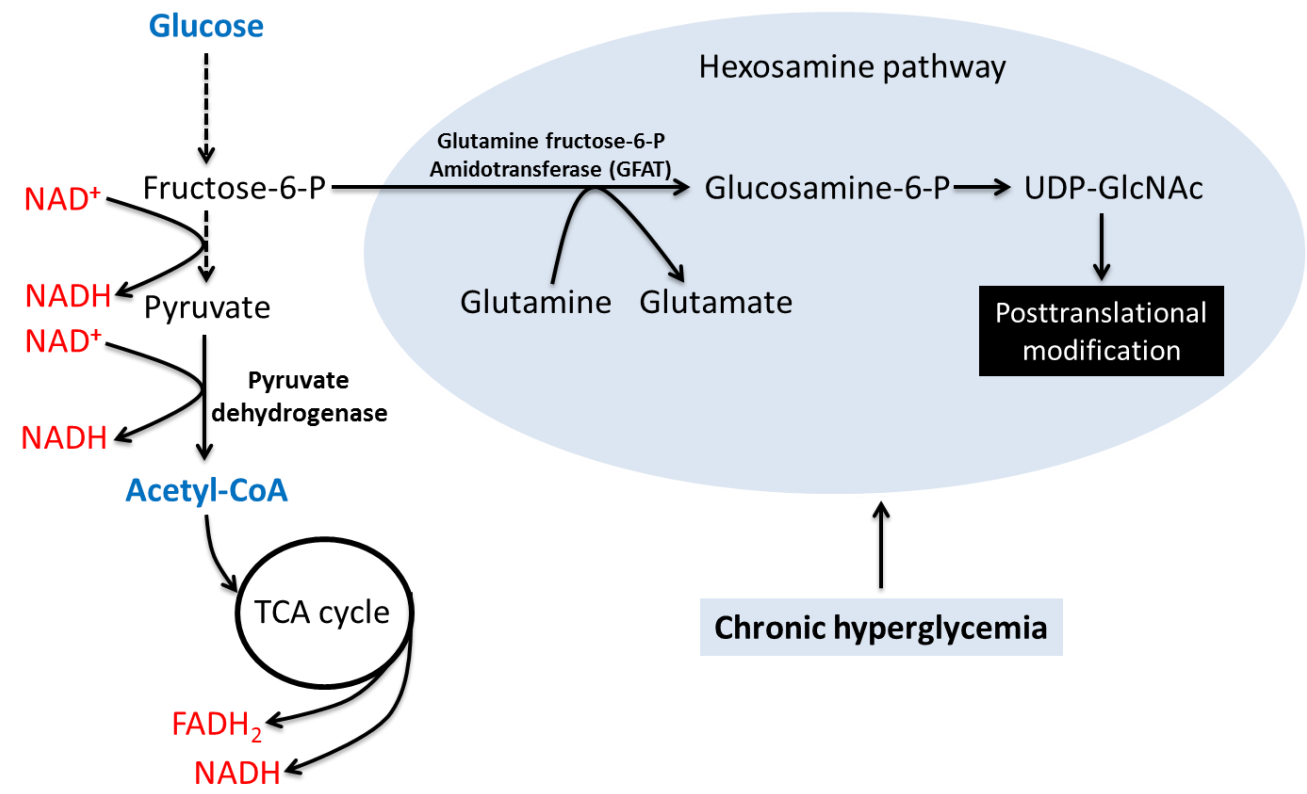

Figure 5. Glucose disposal via the hexosamine pathway. This pathway involves activation of glutamine fructose-6-P amidotransferase that converts fructose 6-P to glucosamine 6-P. This is followed by the formation of UDP-GlcNAc that is the substrate for protein translational modifications. This pathway is known to be involved in insulin resistance and diabetes. The glycolytic pathway is also shown. 
Overall, the toxicity of reductive stress is generally reflected by an increased ratio between NADH and $\mathrm{NAD}^{+}$or redox imbalance between NADH and $\mathrm{NAD}^{+}$, which can impair NAD-dependent enzyme function, deregulate energy metabolism and cell signaling pathways, increase cellular ROS production, and elevates oxidative damage to macromolecules.

\section{The hexosamine pathway}

As shown in Fig. 5, this pathway originates from fructose-6-P in the glycolytic pathway [126, 127]. It is another pathway that is significantly upregulated by chronic hyperglycemia [126-128]. Fructose-6-P is transformed to glucosamine-6-P by the enzyme glutamine fructose-6-P amidotransferase (GFAT), glucosamine then promotes the synthesis of uridine diphosphate-N-acetylhexosamine (UDP-GlcNAc) that then serves as a substrate for $\mathrm{N}$ - or O-glycation of numerous proteins $[129,130]$. It should be noted that the mechanism by which hyperglycemia activates GFAT is poorly understood. This posttranslational modification can enhance glucotoxicity by impairing protein function $[131,132]$ and has been demonstrated to be involved in insulin resistance and pathogenesis of diabetes [133136].

\section{The protein kinase $\mathrm{C}$ (PKC) activation pathway}

This pathway can originate from either fructose-6-P or glyceraldehyde-3-P in the glycolytic pathway (Fig. 1). The initial species formed is dihydroxyacetone that is further converted to glycerol-3-P. Glycerol-3-P then forms diacylglycerol (DAG) that can activate several isoforms of PKC $[137,138]$. PKC then drives numerous signaling processes via protein phosphorylation that regulates signaling protein functions. One of the downstream targets of PKC is known to be NADPH oxidase whose activation drives superoxide production and thus exacerbates oxidative damage to macromolecules thereby enhancing glucotoxicity $[139,140]$.

\section{The advanced glycation end products (AGEs) pathway}

There are two mechanisms by which advanced glycation end products (AGEs) can be formed. The first one is the one shown in Fig. 1 (pathway 4) via the formation of methylglyoxal from glyceraldehyde-3-P [37, 141]. Methylglyoxal then reacts with cysteine, lysine, and arginine residues of proteins, forming advanced glycation end products [142-145]. The second pathway is nonenzymatic, direct attachment of glucose to protein lysine residues via Schiff base formation [53, 146, 147].
The Schiff base then transforms slowly to form stable advanced glycation end products. Many proteins can form AGEs, such as HSP27 [148, 149] and hemoglobin (HbA1c) [27, 150], the quantitation of the latter is often used as an index to measure the progress of diabetes [16]. The glucotoxicity of this pathway has also been demonstrated by observations that the NF-KB signaling pathway can be activated to generate nitric oxide involved in inflammation that can drive the progression of diabetes [151, 152]. Moreover, formation of AGEs can also activate NADPH oxidase [153, 154], leading to superoxide production and oxidative stress. Hence, inhibition of NADH oxidase could preserve islet $\beta$ cell functions and lessens glucotoxicity [155-157].

\section{The enediol pathway}

Chronic hyperglycemia can also elevate the level of enediol, a by-product originated from autoxidation of glyceraldehyde-3-P in the glycolytic pathway [158]. This autoxidation process can generate alpha-ketoaldehyde and ROS, thereby elevating levels of oxidative stress [37]. Formation of enediol has been shown to be involved in pathogenesis of diabetes [159].

\section{Oxidative stress}

Oxidative stress has been thought to play a central role in the pathogenesis of diabetes and its complications [160166]. It is induced by overwhelming production of ROS that can attack macromolecules including lipids, DNA, and proteins [28, 167-170]. ROS can be generated by a variety of systems such as mitochondrial electron transport chain $[168,171,172]$, d-amino acid oxidase [173-175], dihydrolipoamide dehydrogenase [176-182], $\alpha$-keto acid dehydrogenase complex [183-187], NADPH oxidase [188, 189], and xanthine oxidase [190, 191]. It should be noted that in the presence of nitric oxide, superoxide can react with nitric oxide to form peroxynitrite [192, 193], a highly reactive species that is known to exert cytotoxicity via modification of macromolecules [194-196] implicated in diabetes [197201]. Given the role of oxidative stress in diabetes, a variety of antioxidants and phytochemicals have been evaluated for their protective or preventive effects on diabetes and its complications [202-211].

Each of the pathways shown in Fig. 1 can lead to oxidative stress [36, 37]. However, in this section, we would like to focus our discussions on oxidative stress that is preceded by reductive stress in diabetes [36]. As mentioned above, reductive stress is induced by redox imbalance between NADH and $\mathrm{NAD}^{+}$. Moreover, excess NADH can overwhelm mitochondrial complex I (NADH-ubiquinone oxidoreductase), a complex that has 
at least 45 subunits in mammalian cells and serves as the first electron entry point into the mitochondrial electron transport chain [212-216]. As polyol pathway is activated to increase NADH content and poly ADP ribose polymerase is activated to decrease $\mathrm{NAD}^{+}$content [36], cells undergo persistent reductive stress as the overall ratio between $\mathrm{NADH}$ and $\mathrm{NAD}^{+}$is increased [36]. One consequence of this redox imbalance is NADH overload of mitochondrial electron transport chain that is known to be capable of generating most of the ROS under pathological conditions $[217,218]$. While the first three complexes (I to III) can all generate ROS via the formation of superoxide anion, complex I would be the major one that makes more ROS under NADH pressure as it is the only site in mitochondria that makes NAD ${ }^{+}$ from NADH [219, 220]. Furthermore, an inherent feature of complex I is that the more NADH it oxidizes, the more superoxide it would produce [219, 221]. Therefore, as shown in Fig. 6, complex I could be a pathogenic factor in diabetes [222-224] and could also be a promising target for lowering NADH level and ameliorating reductive stress or oxidative stress [225229]. In fact, complex I has been the target for metformin in type 2 diabetes, whereby metformin inhibits complex I [230-232], reduces ATP production, and activates AMPK [223, 233-235], leading to improved metabolism in diabetes [236]. Importantly, the action of metformin seems to exert no cellular toxicity, presumably because fuel combustion via complex II can rescue cells from metformin toxicity [237] (Fig. 6).
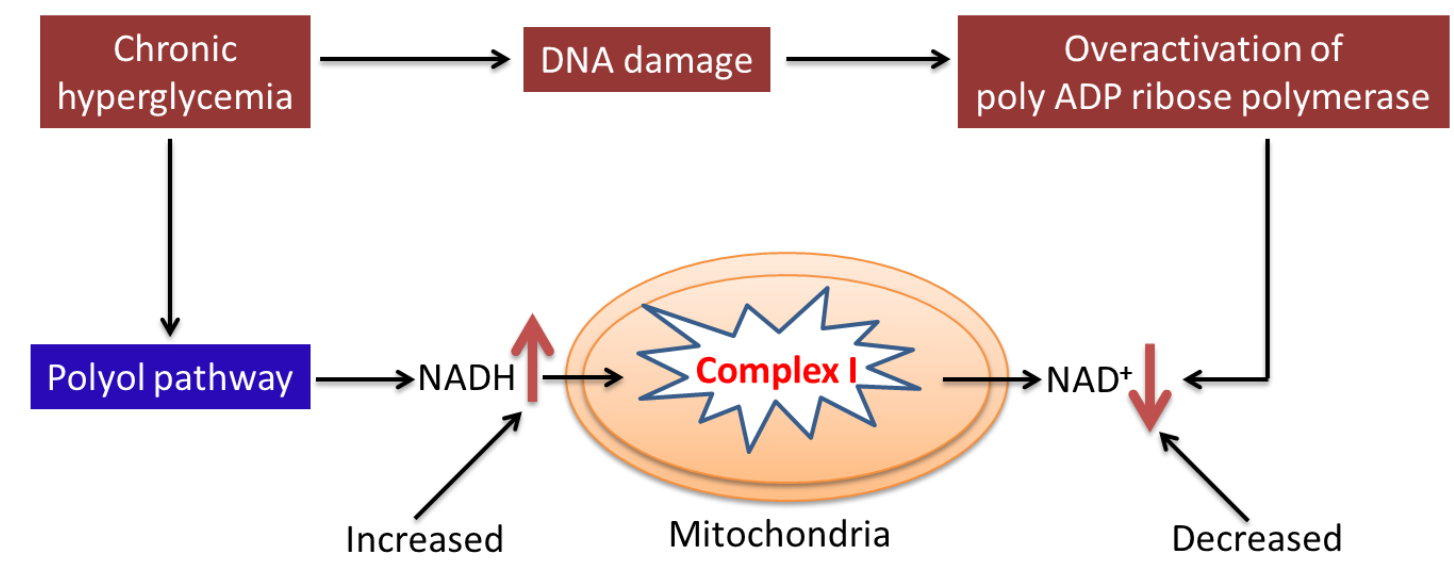

Figure 6. Summary of events leading to redox imbalance between NADH and NAD ${ }^{+}$in diabetes. On one hand, the polyol pathway produces excess $\mathrm{NADH}$; on the other hand, the activation of poly ADP ribose polymerase could potentially deplete $\mathrm{NAD}^{+}$, leading to great pressure on mitochondrial complex I that is in charge of $\mathrm{NADH}$ oxidation and $\mathrm{NAD}^{+}$production. NADH overload on complex I can lead to more ROS production. Therefore, complex I could be a pathogenic factor in diabetes and could also be a target for diabetic therapies.

\section{B. Carbon stress}

A literature search in PubMed indicates that the concept of carbon stress was first mentioned in 1973 by Hopson and Sack in their studies of changes in cellular phosphorus associated with low carbon stress [238]. In the context of hyperglycemia and diabetes, however, we would like to focus on protein acetylation and succination induced, respectively, by excess acetyl-CoA and fumarate as both forms of posttranslational modifications have been implicated in diabetic glucotoxicity $[38,39,239,240]$. It should be noted that over-consumption of alcohol can also lead to carbon stress via protein acetylation, which falls beyond the scope of this review [241, 242].

\section{Protein acetylation}

Excess acetyl-CoA can over-acetylate protein lysine or cysteine residues, leading to protein dysfunction or aberrant protein function $[40,239,243]$. Acetyl-CoA is a central intermediate in metabolism (Fig. 7). On one hand, there are many ways that acetyl-CoA can be produced in a cell. These include pyruvate 
decarboxylation by pyruvate dehydrogenase complex following glycolysis, $\beta$ oxidation of fatty acids, deamination and oxidation of amino acids [244]. On the other hand, acetyl-CoA can be used as a source molecule for the synthesis of sterols and fatty acids, can enter into the TCA cycle for complete degradation to $\mathrm{H}_{2} \mathrm{O}$ and $\mathrm{CO}_{2}$, can form ketone bodies after long term fasting or starvation, and can be used as a substrate for modification of proteins, which is a chemical process that is largely independent of enzymes [241, 245-248]. In diabetes, persistent hyperglycemia itself can raise the level of acetyl-CoA, but persistent hyperglycemia can also enhance fatty acid oxidation that can generate a large amount of acetyl-CoA [44]. It is this chronic excess acetyl-CoA that starts attacking proteins via toxic acetylation mechanisms, thereby leading to impairment in protein function, a process contributing to carbon stress [249]. To cope with this carbon stress, cells have evolved mechanisms of detaching the acetyl groups from over-acetylated proteins, which is achieved by a class of enzymes called sirtuins [250-253] (Fig. 8).

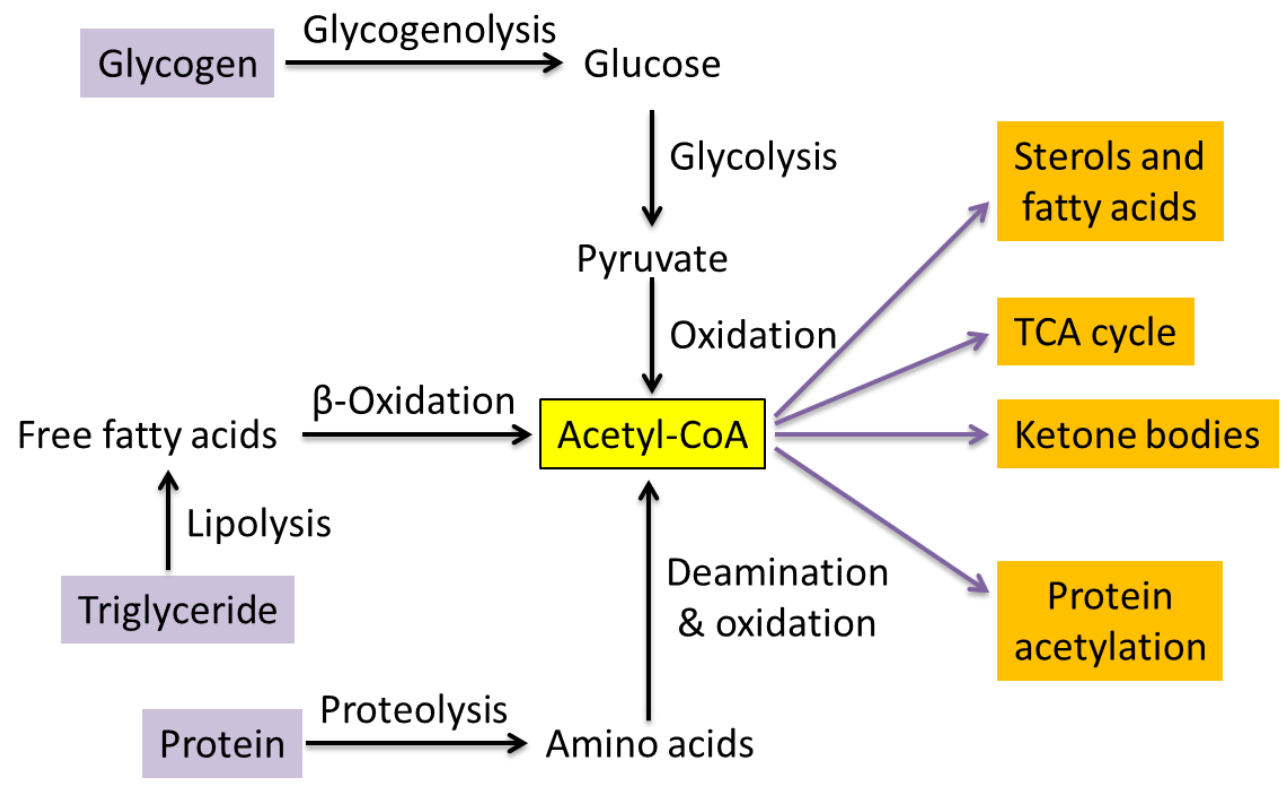

Figure 7. Sources and fates of acetyl-CoA. Acetyl-CoA is mainly generated by combustion of glucose, fatty acid, and proteins. When in excess, acetyl-CoA can be used to make sterols and fatty acids, and can also conjugate to proteins, forming acetylated protein products. In long term fasting or starvation, acetyl-CoA can be used to form ketone bodies that are needed for brain function [288, 289]. Under normal conditions, acetyl-CoA is metabolized to provide energy via TCA cycle and oxidative phosphorylation inside mitochondria.

Sirtuins can be activated under certain stress conditions such as starvation and caloric restriction [254$256]$ to increase the efficiency of metabolism to cope with metabolic stress. However, sirtuins are usually less active under overnutrition conditions such as diabetes because of overproduction of NADH that can inhibit sirtuins activity [257, 258]. This can make acetylation widespread and toxic in the presence of elevated levels of acetyl-CoA [259, 260]. Therefore, sirtuins have been touted as promising targets for diabetic therapy if their activities can be enhanced [261, 262].

However, sirtuins are $\mathrm{NAD}^{+}$-dependent deacetylases and are unfortunately usually down-regulated in diabetes
[251, 263-267]. If sirtuins have to be upregulated to cope with carbon stress, such approaches will certainly lead to more consumption of $\mathrm{NAD}^{+}$, the level of which is already low given the activation of poly ADP ribose polymerase and over production of NADH [36]. Therefore, it seems that upregulation of sirtuins in diabetes will compete for $\mathrm{NAD}^{+}$with other $\mathrm{NAD}^{+}$dependent enzymes such as PARP and CD38 [105, 268270] and thus will aggravate the situation of pseudohypoxia. How this can be reconciled needs to be further investigated before sirtuins can be designed as therapeutic targets for diabetes $[271,272]$. 


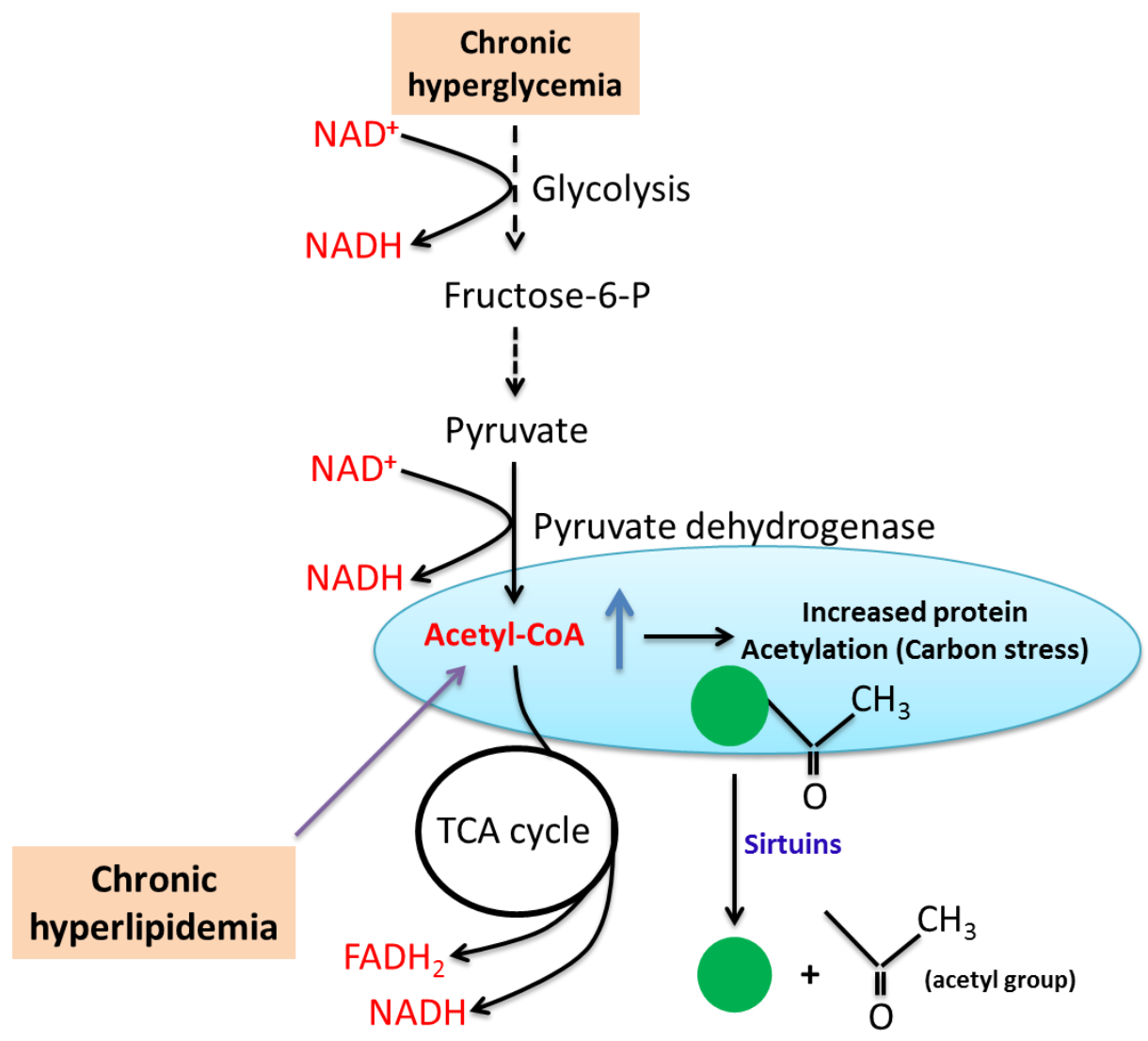

Figure 8. Excess acetyl-CoA produced by hyperglycemia and hyperlipidemia in diabetes can increase nonenzymatic acetylation of proteins via lysine residues. This modification can regulate protein function under stress conditions via sirtuins actions that remove the acetyl groups from the target proteins.

\section{Protein succination}

Protein succination [39, 273, 274], another form of carbon stress, originates from fumarate [240, 275-277] that is an intermediate in the TCA cycle. When the level of acetyl-CoA is elevated, so is the level of fumarate. Fumarate can then attack protein cysteine residues, resulting in protein succination [240, 278]. Succination can also occur to glutathione [279]. This modification can severely disrupt protein functions given that protein cysteine residues are intricately involved in protein function and redox signaling [280-287]. For example, GAPDH could be inactivated via succination in diabetes [39, 277]. Moreover, in mitochondria, increased succination has been linked to glucotoxicity under hyperglycemia or in diabetes [240]. It should be noted that given the observations that both acetylation of lysine residues and succination of cysteine residues are linked to glucotoxicity, carbon stress may also be placed conceptually under hyperglycemia stress.

\section{Summary and perspectives}

In this article, we have reviewed the concept of diabetic glucotoxicity. We classified diabetic glucotoxicity into two categories of stress: hyperglycemic stress and carbon stress. Under hyperglycemic stress, we discussed several mechanisms of glucotoxicity such as reductive or pseudohypoxic stress, the polyol pathway, the hexosamine pathway, the PKC pathway, the AGEs pathway, and the enediol pathway. We emphasize that all the pathways culminate on oxidative stress [37]. As redox imbalance between $\mathrm{NADH}$ and $\mathrm{NAD}^{+}$is the precursor of oxidative stress [36], we further discussed 
the role of mitochondrial complex I in glucotoxicity as this complex can produce more ROS in the presence of hyperglycemia and excess NADH and is responsible for mitochondrial regeneration of $\mathrm{NAD}^{+}$. We think that complex I can be both a pathogenic factor and a potential therapeutic target in diabetes. Under carbon stress, we focused on protein acetylation and succination; both of which can manifest diabetic glucotoxicity. In the context of protein acetylation, we touched on sirtuins that are acetylases capable of improving metabolism by removing acetyl groups off from target proteins. Future in-depth studies targeting these hyperglycemic- and carbon stress pathways may help design novel strategies for treatment of diabetes and its complications.

\section{Acknowledgements}

L.J.Y. was supported in part by National Institute of Neurological Disorders and Stroke (Grant: R01NS079792).

\section{Conflict of interests}

The authors declare that there is no conflict of interests

\section{References}

[1] Bensellam M, Laybutt DR, Jonas JC (2012). The molecular mechanisms of pancreatic beta-cell glucotoxicity: recent findings and future research directions. Molecular and cellular endocrinology, 364: $1-27$

[2] Del Prato S (2009). Role of glucotoxicity and lipotoxicity in the pathophysiology of Type 2 diabetes mellitus and emerging treatment strategies. Diabet Med, 26: 1185-1192

[3] Dedoussis GV, Kaliora AC, Panagiotakos DB (2007). Genes, diet and type 2 diabetes mellitus: a review. The review of diabetic studies : RDS, 4: 13-24

[4] Somesh BP, Verma MK, Sadasivuni MK, MammenOommen A, Biswas S, Shilpa PC, et al. (2013). Chronic glucolipotoxic conditions in pancreatic islets impair insulin secretion due to dysregulated calcium dynamics, glucose responsiveness and mitochondrial activity. BMC Cell Biol, 14: 31

[5] Leibowitz G, Kaiser N, Cerasi E (2011). beta-Cell failure in type 2 diabetes. Journal of diabetes investigation, 2: 82-91

[6] Leibowitz G, Bachar E, Shaked M, Sinai A, KetzinelGilad M, Cerasi E, et al. (2010). Glucose regulation of beta-cell stress in type 2 diabetes. Diabetes, obesity \& metabolism, 12 Suppl 2: 66-75

[7] Barnett AH (2012) Type 2 diabetes, Oxford University Press

[8] Ruderman NB, Carling D, Prentki M, Cacicedo JM (2013). AMPK, insulin resistance, and the metabolic syndrome. J Clin Invest, 123: 2764-2772
[9] Bacha F, Gungor N, Lee S, Arslanian SA (2013). Progressive deterioration of beta-cell function in obese youth with type 2 diabetes. Pediatr Diabetes, 14: 106-111

[10] Gallwitz B, Kazda C, Kraus P, Nicolay C, Schernthaner G (2013). Contribution of insulin deficiency and insulin resistance to the development of type 2 diabetes: nature of early stage diabetes. Acta Diabetol, 50: 39-45

[11] DeFronzo RA (1997). Insulin resistance: a multifaceted syndrome responsible for NIDDM, obesity, hypertension, dyslipidaemia and atherosclerosis. The Netherlands journal of medicine, 50: 191-197

[12] Abdul-Ghani MA, DeFronzo RA (2010). Pathogenesis of insulin resistance in skeletal muscle. Journal of biomedicine \& biotechnology, 2010: 476279

[13] Gungor N, Arslanian S (2004). Progressive beta cell failure in type 2 diabetes mellitus of youth. J Pediatr, 144: 656-659

[14] Funk SD, Yurdagul A, Jr., Orr AW (2012). Hyperglycemia and endothelial dysfunction in atherosclerosis: lessons from type 1 diabetes. International journal of vascular medicine, 2012: 569654

[15] Eiselein L, Schwartz HJ, Rutledge JC (2004). The challenge of type 1 diabetes mellitus. ILAR journal / National Research Council, Institute of Laboratory Animal Resources, 45: 231-236

[16] Tuch B, Dunlop M, Proietto J (2000) Diabetes Research: A guide for postgraduates, Harwood Academic Publishers

[17] Larsen MO (2009). Beta-cell function and mass in type 2 diabetes. Danish medical bulletin, 56: 153-164

[18] Butler AE, Janson J, Bonner-Weir S, Ritzel R, Rizza RA, Butler PC (2003). Beta-cell deficit and increased beta-cell apoptosis in humans with type 2 diabetes. Diabetes, 52: 102-110

[19] Abdul-Ghani MA, DeFronzo RA (2008) Oxidative stress in type 2 diabetes. In Oxidative stress in aging (Miwa, S., Beckman, K. B., Muller, F. L., eds) pp. 191-212, Humana Press

[20] Kaiser N, Leibowitz G, Nesher R (2003). Glucotoxicity and beta-cell failure in type 2 diabetes mellitus. J Pediatr Endocrinol Metab, 16: 5-22

[21] Szendroedi J, Phielix E, Roden M (2012). The role of mitochondria in insulin resistance and type 2 diabetes mellitus. Nature reviews. Endocrinology, 8: 92-103

[22] Maedler K, Donath MY (2004). Beta-cells in type 2 diabetes: a loss of function and mass. Horm Res, 62 Suppl 3: 67-73

[23] Chang-Chen KJ, Mullur R, Bernal-Mizrachi E (2008). Beta-cell failure as a complication of diabetes. Rev Endocr Metab Disord, 9: 329-343

[24] Muoio DM, Newgard CB (2008). Mechanisms of disease: molecular and metabolic mechanisms of insulin resistance and beta-cell failure in type 2 diabetes. Nature reviews. Molecular cell biology, 9: 193-205 
[25] Lee SA, Lee WJ, Kim EH, Yu JH, Jung CH, Koh $\mathrm{EH}$, et al. (2011). Progression to insulin deficiency in Korean patients with Type 2 diabetes mellitus positive for anti-GAD antibody. Diabet Med, 28: 319-324

[26] Cnop M, Welsh N, Jonas JC, Jorns A, Lenzen S, Eizirik DL (2005). Mechanisms of pancreatic betacell death in type 1 and type 2 diabetes: many differences, few similarities. Diabetes, 54 Suppl 2: S97-107

[27] Gholap NN, Davies MJ, Mostafa SA, Khunti K (2013). Diagnosing type 2 diabetes and identifying high-risk individuals using the new glycated haemoglobin $(\mathrm{HbA} 1 \mathrm{c})$ criteria. The British journal of general practice : the journal of the Royal College of General Practitioners, 63: e165-167

[28] Wu J, Luo X, Yan LJ (2015). Two dimensional blue native/SDS-PAGE to identify mitochondrial complex I subunits modified by 4-hydroxynonenal (HNE). Frontiers in Physiology, 6

[29] Korsgren O, Jansson L, Sandler S, Andersson A (1990). Hyperglycemia-induced B cell toxicity. The fate of pancreatic islets transplanted into diabetic mice is dependent on their genetic background. J Clin Invest, 86: 2161-2168

[30] Poitout V, Robertson RP (2002). Minireview: Secondary beta-cell failure in type 2 diabetes--a convergence of glucotoxicity and lipotoxicity. Endocrinology, 143: 339-342

[31] Roseman HM (2005). Progression from obesity to type 2 diabetes: lipotoxicity, glucotoxicity, and implications for management. Journal of managed care pharmacy : JMCP, 11: S3-S11

[32] Weir GC, Marselli L, Marchetti P, Katsuta H, Jung MH, Bonner-Weir S (2009). Towards better understanding of the contributions of overwork and glucotoxicity to the beta-cell inadequacy of type 2 diabetes. Diabetes, obesity \& metabolism, 11 Suppl 4: $82-90$

[33] Poitout V, Robertson RP (2008). Glucolipotoxicity: fuel excess and beta-cell dysfunction. Endocrine reviews, 29: 351-366

[34] Kawahito S, Kitahata H, Oshita S (2009). Problems associated with glucose toxicity: role of hyperglycemia-induced oxidative stress. World J Gastroenterol, 15: 4137-4142

[35] Giaccari A, Sorice G, Muscogiuri G (2009). Glucose toxicity: the leading actor in the pathogenesis and clinical history of type 2 diabetes - mechanisms and potentials for treatment. Nutr Metab Cardiovasc Dis, 19: 365-377

[36] Yan LJ (2014). Pathogenesis of Chronic Hyperglycemia: From Reductive Stress to Oxidative Stress. Journal of diabetes research, 2014: 137919

[37] Robertson RP (2004). Chronic oxidative stress as a central mechanism for glucose toxicity in pancreatic islet beta cells in diabetes. J Biol Chem, 279: 4235142354
[38] Iyer A, Fairlie DP, Brown L (2012). Lysine acetylation in obesity, diabetes and metabolic disease. Immunol Cell Biol, 90: 39-46

[39] Frizzell N, Lima M, Baynes JW (2011). Succination of proteins in diabetes. Free Radic Res, 45: 101-109

[40] Wagner GR, Hirschey MD (2014). Nonenzymatic protein acylation as a carbon stress regulated by sirtuin deacylases. Mol Cell, 54: 5-16

[41] Abel ED (2010). Free fatty acid oxidation in insulin resistance and obesity. Heart Metab, 48: 5-10

[42] Poretsky L (2010) Principles of diabetes mellitus, Springer, New York

[43] de Koning L, Amlik VS, Hu FB (2014) Dietary carbohydrates and type 2 diabetes. In Nutrition and type 2 diabetes etiology and prevention (Pereira, $\mathrm{M}$. A., ed) pp. 11-64, CRC Press, New York

[44] Seely L, Olefsky JM (1993) Potential cellular and genetic mechanisms for insulin resistance in the common disorders of diabetes and obesity. In Insulin resistance (Moller, D. E., ed) pp. 187-252, Wiley, New York

[45] Cook JR, Langlet F, Kido Y, Accili D (2015). On the Pathogenesis of Selective Insulin Resistance in Isolated Hepatocytes. J Biol Chem,

[46] Sajan MP, Jurzak MJ, Samuels VT, Shulman GI, Braun U, Leitges M, et al. (2014). Impairment of insulin-stimulated glucose transport and ERK activation by adipocyte-specific knockout of PKClambda produces a phenotype characterized by diminished adiposity and enhanced insulin suppression of hepatic gluconeogenesis. Adipocyte, 3: $19-29$

[47] Turner N, Cooney GJ, Kraegen EW, Bruce CR (2014). Fatty acid metabolism, energy expenditure and insulin resistance in muscle. J Endocrinol, 220: T61-79

[48] Yang J (2014). Enhanced skeletal muscle for effective glucose homeostasis. Prog Mol Biol Transl Sci, 121: 133-163

[49] Gustafson B, Hedjazifar S, Gogg S, Hammarstedt A, Smith U (2015). Insulin resistance and impaired adipogenesis. Trends Endocrinol Metab, 26: 193-200

[50] Yki-Jarvinen H (2002). Insulin resistance in patients with IDDM. In: Hormone resistance and hypersensitivity states. Lippincott William \& Wilkins, Baltimore, 175-185

[51] Groop L, Orho M (1998). Metabolic aspects of glycogen synthase activation. In: Molecular and cell biology of type 2 diabetes and its complications. Karger, Basel,47-55

[52] Stolar M (2010). Glycemic control and complications in type 2 diabetes mellitus. The American journal of medicine, 123: S3-11

[53] Brownlee M (2001). Biochemistry and molecular cell biology of diabetic complications. Nature, 414: 813820

[54] Brownlee M (2005). The pathobiology of diabetic complications: a unifying mechanism. Diabetes, 54: $1615-1625$ 
[55] Finocchietto P, Barreyro F, Holod S, Peralta J, Franco MC, Mendez C, et al. (2008). Control of muscle mitochondria by insulin entails activation of Akt2-mtNOS pathway: implications for the metabolic syndrome. PLoS ONE, 3: e1749

[56] Cheng Z, Tseng Y, White MF (2010). Insulin signaling meets mitochondria in metabolism. Trends Endocrinol Metab, 21: 589-598

[57] Cline GW (2011). Fuel-Stimulated Insulin Secretion Depends upon Mitochondria Activation and the Integration of Mitochondrial and Cytosolic Substrate Cycles. Diabetes Metab J, 35: 458-465

[58] White MF, Khan CR (1993) Mechanisms of insulin action. In Insulin resistance (Moller, D. E., ed) pp. 947, Wiley, New York

[59] Brunner Y, Schvartz D, Priego-Capote F, Coute Y, Sanchez JC (2009). Glucotoxicity and pancreatic proteomics. J Proteomics, 71: 576-591

[60] Seltzer HS, Harris VL (1964). Exhaustion of Insulogenic Reserve in Maturity-Onset Diabetic Patients during Prolonged and Continuous Hyperglycemic Stress. Diabetes, 13: 6-13

[61] Lipinski B (2002). Evidence in support of a concept of reductive stress. The British journal of nutrition, 87: 93-94; discussion 94

[62] Teodoro JS, Rolo AP, Palmeira CM (2013). The NAD ratio redox paradox: why does too much reductive power cause oxidative stress? Toxicology Mechanisms and Methods, 23: 297-302

[63] Pung YF, Chilian WM (2010). Corruption of coronary collateral growth in metabolic syndrome: Role of oxidative stress. World journal of cardiology, 2: $421-427$

[64] Tilton RG (2002). Diabetic vascular dysfunction: links to glucose-induced reductive stress and VEGF. Microscopy research and technique, 57: 390-407

[65] Valadi H, Valadi A, Ansell R, Gustafsson L, Adler L, Norbeck J, et al. (2004). NADH-reductive stress in Saccharomyces cerevisiae induces the expression of the minor isoform of glyceraldehyde-3-phosphate dehydrogenase (TDH1). Current genetics, 45: 90-95

[66] Chung SS, Chung SK (2005). Aldose reductase in diabetic microvascular complications. Curr Drug Targets, 6: 475-486

[67] Dunlop M (2000). Aldose reductase and the role of the polyol pathway in diabetic nephropathy. Kidney Int Suppl, 77: S3-12

[68] Hodgkinson AD, Sondergaard KL, Yang B, Cross DF, Millward BA, Demaine AG (2001). Aldose reductase expression is induced by hyperglycemia in diabetic nephropathy. Kidney Int, 60: 211-218

[69] Iwata K, Nishinaka T, Matsuno K, Kakehi T, Katsuyama M, Ibi M, et al. (2007). The activity of aldose reductase is elevated in diabetic mouse heart. $\mathrm{J}$ Pharmacol Sci, 103: 408-416

[70] Yabe-Nishimura C (1998). Aldose reductase in glucose toxicity: a potential target for the prevention of diabetic complications. Pharmacol Rev, 50: 21-33
Tang WH, Martin KA, Hwa J (2012). Aldose reductase, oxidative stress, and diabetic mellitus. Frontiers in pharmacology, 3: 87

Fantus IG (2002). The pathogenesis of the chronic complications of the diabetes mellitus. Endocrinology Rounds, 2: 1-8

Gomes AP, Price NL, Ling AJ, Moslehi JJ, Montgomery MK, Rajman L, et al. (2013). Declining $\mathrm{NAD}(+)$ induces a pseudohypoxic state disrupting nuclear-mitochondrial communication during aging. Cell, 155: 1624-1638

Ido Y, Williamson JR (1997). Hyperglycemic cytosolic reductive stress 'pseudohypoxia': implications for diabetic retinopathy. Invest Ophthalmol Vis Sci, 38: 1467-1470

Williamson JR, Chang K, Frangos M, Hasan KS, Ido Y, Kawamura T, et al. (1993). Hyperglycemic pseudohypoxia and diabetic complications. Diabetes, 42: 801-813

Hotta N (1997). New concepts and insights on pathogenesis and treatment of diabetic complications: polyol pathway and its inhibition. Nagoya J Med Sci, 60: 89-100

Yasunari K, Kohno M, Kano H, Minami M, Yoshikawa J (2000). Aldose reductase inhibitor improves insulin-mediated glucose uptake and prevents migration of human coronary artery smooth muscle cells induced by high glucose. Hypertension, 35: 1092-1098

Chavez JC, Agani F, Pichiule P, LaManna JC (2000). Expression of hypoxia-inducible factor-1alpha in the brain of rats during chronic hypoxia. J Appl Physiol (1985), 89: 1937-1942

Benderro GF, LaManna JC (2013). Kidney EPO expression during chronic hypoxia in aged mice. Adv Exp Med Biol, 765: 9-14

Li R, Luo X, Wu J, Thangthaeng N, Jung ME, Jing S, et al. (2015). Mitochondrial dihydrolipoamide dehydrogenase is upregulated in response to intermittent hypoxic preconditioning. Int. J. Med. Sci., 12: 432-440

Houtkooper RH, Canto C, Wanders RJ, Auwerx J (2010). The secret life of NAD+: an old metabolite controlling new metabolic signaling pathways. Endocrine reviews, 31: 194-223

Braidy N, Guillemin GJ, Mansour H, Chan-Ling T, Poljak A, Grant R (2011). Age related changes in NAD+ metabolism oxidative stress and Sirt1 activity in wistar rats. PLoS One, 6: e19194

Chiarugi A, Dolle C, Felici R, Ziegler M (2012). The NAD metabolome--a key determinant of cancer cell biology. Nat Rev Cancer, 12: 741-752

Houtkooper RH, Auwerx J (2012). Exploring the therapeutic space around NAD+. J Cell Biol, 199: 205-209

Chandra D, Jackson EB, Ramana KV, Kelley R, Srivastava SK, Bhatnagar A (2002). Nitric oxide prevents aldose reductase activation and sorbitol accumulation during diabetes. Diabetes, 51: 30953101 
[86] Lee AY, Chung SS (1999). Contributions of polyol pathway to oxidative stress in diabetic cataract. FASEB J, 13: 23-30

[87] Obrosova IG (2005). Increased sorbitol pathway activity generates oxidative stress in tissue sites for diabetic complications. Antioxid Redox Signal, 7: 1543-1552

[88] Harding JJ, Blakytny R, Ganea E (1996). Glutathione in disease. Biochem Soc Trans, 24: 881-884

[89] Yan LJ, Christians ES, Liu L, Xiao X, Sohal RS, Benjamin IJ (2002). Mouse heat shock transcription factor 1 deficiency alters cardiac redox homeostasis and increases mitochondrial oxidative damage. EMBO J, 21: 5164-5172

[90] Lou MF, Dickerson JE, Jr., Garadi R, York BM, Jr. (1988). Glutathione depletion in the lens of galactosemic and diabetic rats. Experimental eye research, 46: 517-530

[91] Sato T, Sasaki H, Watanabe R, Yoshinaga K (1988). Enhancement of pentose phosphate pathway in vascular intima from diabetic rabbit. Tohoku J Exp Med, 155: 97-100

[92] Rosa AP, Jacques CE, de Souza LO, Bitencourt F, Mazzola PN, Coelho JG, et al. (2015). Neonatal hyperglycemia induces oxidative stress in the rat brain: the role of pentose phosphate pathway enzymes and NADPH oxidase. Mol Cell Biochem, 403: $159-167$

[93] Bast A, Haenen GR (2002) Lipoic acid: a multifunctional antioxidant. In Thiol metabolism and redox regulation of cellular function (Pompella, A., Banhegyi, G., Wellman-Rousseau, M., eds) pp. 230237, IOS Press, Amsterdam, Netherlands

[94] Winkler BS, DeSantis N, Solomon F (1986). Multiple NADPH-producing pathways control glutathione (GSH) content in retina. Experimental eye research, 43: 829-847

[95] Tang WH, Wu S, Wong TM, Chung SK, Chung SS (2008). Polyol pathway mediates iron-induced oxidative injury in ischemic-reperfused rat heart. Free Radic Biol Med, 45: 602-610

[96] Yang Y, Hayden MR, Sowers S, Bagree SV, Sowers JR (2010). Retinal redox stress and remodeling in cardiometabolic syndrome and diabetes. Oxid Med Cell Longev, 3: 392-403

[97] Ussher JR, Jaswal JS, Lopaschuk GD (2012). Pyridine nucleotide regulation of cardiac intermediary metabolism. Circ Res, 111: 628-641

[98] Suzen S, Buyukbingol E (2003). Recent studies of aldose reductase enzyme inhibition for diabetic complications. Curr Med Chem, 10: 1329-1352

[99] Reddy AB, Ramana KV (2010). Aldose reductase inhibition: emerging drug target for the treatment of cardiovascular complications. Recent Pat Cardiovasc Drug Discov, 5: 25-32

[100] Tang J, Du Y, Petrash JM, Sheibani N, Kern TS (2013). Deletion of aldose reductase from mice inhibits diabetes-induced retinal capillary degeneration and superoxide generation. PLoS One, 8: e62081
[101] Alzaid A, Rizza RA (1993). Insulin resistance and its role in the pathogenesis of impaired glucose tolerance and non-insulin-dependent diabetes mellitus: perspectives gained from in vivo studies. In: Insulin resistance. John Wiley \& Sons Ltd, New York, 143186

[102] Bevilacqua S, Buzzigoli G, Bonadonna R, Brandi LS, Oleggini M, Boni C, et al. (1990). Operation of Randle's cycle in patients with NIDDM. Diabetes, 39: 383-389

[103] Nuutila P, Koivisto VA, Knuuti J, Ruotsalainen U, Teras M, Haaparanta M, et al. (1992). Glucose-free fatty acid cycle operates in human heart and skeletal muscle in vivo. J Clin Invest, 89: 1767-1774

[104] Ferrannini E, Barrett EJ, Bevilacqua S, DeFronzo RA (1983). Effect of fatty acids on glucose production and utilization in man. J Clin Invest, 72: 1737-1747

[105] Dolle C, Rack JG, Ziegler M (2013). NAD and ADPribose metabolism in mitochondria. FEBS J, 280: 3530-3541

[106] Ying W (2008). NAD+/NADH and NADP+/NADPH in cellular functions and cell death: regulation and biological consequences. Antioxid Redox Signal, 10: 179-206

[107] Szabados E, Fischer GM, Gallyas F, Jr., Kispal G, Sumegi B (1999). Enhanced ADP-ribosylation and its diminution by lipoamide after ischemia-reperfusion in perfused rat heart. Free Radic Biol Med, 27: 11031113

[108] Szabo C (2005). Roles of poly(ADP-ribose) polymerase activation in the pathogenesis of diabetes mellitus and its complications. Pharmacol Res, 52: 60-71

[109] Pittelli M, Felici R, Pitozzi V, Giovannelli L, Bigagli E, Cialdai F, et al. (2011). Pharmacological effects of exogenous NAD on mitochondrial bioenergetics, DNA repair, and apoptosis. Mol Pharmacol, 80: 1136-1146

[110] Szabo C, Zanchi A, Komjati K, Pacher P, Krolewski AS, Quist WC, et al. (2002). Poly(ADP-Ribose) polymerase is activated in subjects at risk of developing type 2 diabetes and is associated with impaired vascular reactivity. Circulation, 106: 26802686

[111] Pacher P, Liaudet L, Soriano FG, Mabley JG, Szabo E, Szabo C (2002). The role of poly(ADP-ribose) polymerase activation in the development of myocardial and endothelial dysfunction in diabetes. Diabetes, 51: 514-521

[112] Horvath EM, Magenheim R, Kugler E, Vacz G, Szigethy A, Levardi F, et al. (2009). Nitrative stress and poly(ADP-ribose) polymerase activation in healthy and gestational diabetic pregnancies. Diabetologia, 52: 1935-1943

[113] Du X, Matsumura T, Edelstein D, Rossetti L, Zsengeller Z, Szabo C, et al. (2003). Inhibition of GAPDH activity by poly(ADP-ribose) polymerase activates three major pathways of hyperglycemic damage in endothelial cells. J Clin Invest, 112: 10491057 
[114] Pacher P, Szabo C (2005). Role of poly(ADP-ribose) polymerase-1 activation in the pathogenesis of diabetic complications: endothelial dysfunction, as a common underlying theme. Antioxid Redox Signal, 7: $1568-1580$

[115] Obrosova IG, Drel VR, Pacher P, Ilnytska O, Wang ZQ, Stevens MJ, et al. (2005). Oxidative-nitrosative stress and poly(ADP-ribose) polymerase (PARP) activation in experimental diabetic neuropathy: the relation is revisited. Diabetes, 54: 3435-3441

[116] Chiu J, Xu BY, Chen S, Feng B, Chakrabarti S (2008). Oxidative stress-induced, poly(ADP-ribose) polymerase-dependent upregulation of ET-1 expression in chronic diabetic complications. Can J Physiol Pharmacol, 86: 365-372

[117] Puthanveetil P, Zhang D, Wang Y, Wang F, Wan A, Abrahani A, et al. (2012). Diabetes triggers a PARP1 mediated death pathway in the heart through participation of FoxO1. J Mol Cell Cardiol, 53: 677686

[118] Masutani M, Suzuki H, Kamada N, Watanabe M, Ueda O, Nozaki T, et al. (1999). Poly(ADP-ribose) polymerase gene disruption conferred mice resistant to streptozotocin-induced diabetes. Proc Natl Acad Sci U S A, 96: 2301-2304

[119] Pieper AA, Brat DJ, Krug DK, Watkins CC, Gupta A, Blackshaw S, et al. (1999). Poly(ADP-ribose) polymerase-deficient mice are protected from streptozotocin-induced diabetes. Proc Natl Acad Sci U S A, 96: 3059-3064

[120] Virag L, Szabo C (2002). The therapeutic potential of poly(ADP-ribose) polymerase inhibitors. Pharmacol Rev, 54: 375-429

[121] Long CA, Boulom V, Albadawi H, Tsai S, Yoo HJ, Oklu R, et al. (2013). Poly-ADP-ribose-polymerase inhibition ameliorates hind limb ischemia reperfusion injury in a murine model of type 2 diabetes. Ann Surg, 258: 1087-1095

[122] Sarras MP, Jr., Mason S, McAllister G, Intine RV (2014). Inhibition of poly-ADP ribose polymerase enzyme activity prevents hyperglycemia-induced impairment of angiogenesis during wound healing. Wound Repair Regen, 22: 666-670

[123] Szkudelski T (2012). Streptozotocin-nicotinamideinduced diabetes in the rat. Characteristics of the experimental model. Exp Biol Med (Maywood), 237: 481-490

[124] Fukaya M, Tamura Y, Chiba Y, Tanioka T, Mao J, Inoue Y, et al. (2013). Protective effects of a nicotinamide derivative, isonicotinamide, against streptozotocin-induced beta-cell damage and diabetes in mice. Biochem Biophys Res Commun, 442: 92-98

[125] Obrosova IG, Minchenko AG, Frank RN, Seigel GM, Zsengeller Z, Pacher P, et al. (2004). Poly(ADPribose) polymerase inhibitors counteract diabetesand hypoxia-induced retinal vascular endothelial growth factor overexpression. Int J Mol Med, 14: 5564

[126] Beyer AM, Weihrauch D (2012). Hexosamine pathway activation and O-linked-N- acetylglucosamine: novel mediators of endothelial dysfunction in hyperglycemia and diabetes. Vascul Pharmacol, 56: 113-114

[127] Schleicher ED, Weigert C (2000). Role of the hexosamine biosynthetic pathway in diabetic nephropathy. Kidney Int Suppl, 77: S13-18

[128] Yki-Jarvinen H, Daniels MC, Virkamaki A, Makimattila S, DeFronzo RA, McClain D (1996). Increased glutamine:fructose-6-phosphate amidotransferase activity in skeletal muscle of patients with NIDDM. Diabetes, 45: 302-307

[129] Yki-Jarvinen H, Vogt C, Iozzo P, Pipek R, Daniels MC, Virkamaki A, et al. (1997). UDP-Nacetylglucosamine transferase and glutamine: fructose 6-phosphate amidotransferase activities in insulin-sensitive tissues. Diabetologia, 40: 76-81

[130] Ma J, Hart GW (2013). Protein O-GlcNAcylation in diabetes and diabetic complications. Expert review of proteomics, 10: 365-380

[131] Issad T, Kuo M (2008). O-GlcNAc modification of transcription factors, glucose sensing and glucotoxicity. Trends Endocrinol Metab, 19: 380-389

[132] Kuo M, Zilberfarb V, Gangneux N, Christeff N, Issad $\mathrm{T}$ (2008). O-GlcNAc modification of FoxO1 increases its transcriptional activity: a role in the glucotoxicity phenomenon? Biochimie, 90: 679-685

[133] Hardiville S, Hart GW (2014). Nutrient regulation of signaling, transcription, and cell physiology by $\mathrm{O}$ GlcNAcylation. Cell Metab, 20: 208-213

[134] Semba RD, Huang H, Lutty GA, Van Eyk JE, Hart GW (2014). The role of O-GlcNAc signaling in the pathogenesis of diabetic retinopathy. Proteomics. Clinical applications, 8: 218-231

[135] Lima VV, Spitler K, Choi H, Webb RC, Tostes RC (2012). O-GlcNAcylation and oxidation of proteins: is signalling in the cardiovascular system becoming sweeter? Clin Sci (Lond), 123: 473-486

[136] Issad T, Masson E, Pagesy P (2010). O-GlcNAc modification, insulin signaling and diabetic complications. Diabetes \& metabolism, 36: 423-435

[137] Xia L, Wang H, Munk S, Frecker H, Goldberg HJ, Fantus IG, et al. (2007). Reactive oxygen species, PKC-beta1, and PKC-zeta mediate high-glucoseinduced vascular endothelial growth factor expression in mesangial cells. American journal of physiology. Endocrinology and metabolism, 293: E1280-1288

[138] Xia L, Wang H, Munk S, Kwan J, Goldberg HJ, Fantus IG, et al. (2008). High glucose activates PKCzeta and NADPH oxidase through autocrine TGFbeta1 signaling in mesangial cells. American journal of physiology. Renal physiology, 295: F1705-1714

[139] Bey EA, Xu B, Bhattacharjee A, Oldfield CM, Zhao $\mathrm{X}$, Li Q, et al. (2004). Protein kinase C delta is required for p47phox phosphorylation and translocation in activated human monocytes. J Immunol, 173: 5730-5738

[140] Fontayne A, Dang PM, Gougerot-Pocidalo MA, ElBenna J (2002). Phosphorylation of p47phox sites by PKC alpha, beta II, delta, and zeta: effect on binding 
to p22phox and on NADPH oxidase activation. Biochemistry, 41: 7743-7750

[141] Thornalley PJ, Langborg A, Minhas HS (1999). Formation of glyoxal, methylglyoxal and 3deoxyglucosone in the glycation of proteins by glucose. Biochem J, 344 Pt 1: 109-116

[142] Dmitriev LF, Dugin SF (2007). Aldehydes and disturbance of carbohydrate metabolism: some consequences and possible approaches to its normalization. Arch Physiol Biochem, 113: 87-95

[143] Allaman I, Belanger M, Magistretti PJ (2015). Methylglyoxal, the dark side of glycolysis. Front Neurosci, 9: 23

[144] Maessen DE, Stehouwer CD, Schalkwijk CG (2015). The role of methylglyoxal and the glyoxalase system in diabetes and other age-related diseases. Clin Sci (Lond), 128: 839-861

[145] Queisser MA, Yao D, Geisler S, Hammes HP, Lochnit G, Schleicher ED, et al. (2010). Hyperglycemia impairs proteasome function by methylglyoxal. Diabetes, 59: 670-678

[146] Wolff SP, Jiang ZY, Hunt JV (1991). Protein glycation and oxidative stress in diabetes mellitus and ageing. Free Radic Biol Med, 10: 339-352

[147] Tomlinson DR, Gardiner NJ (2008). Glucose neurotoxicity. Nat Rev Neurosci, 9: 36-45

[148] Gawlowski T, Stratmann B, Stork I, Engelbrecht B, Brodehl A, Niehaus K, et al. (2009). Heat shock protein 27 modification is increased in the human diabetic failing heart. Hormone and metabolic research $=$ Hormon- und Stoffwechselforschung = Hormones et metabolisme, 41: 594-599

[149] Schalkwijk CG, van Bezu J, van der Schors RC, Uchida K, Stehouwer CD, van Hinsbergh VW (2006). Heat-shock protein 27 is a major methylglyoxal-modified protein in endothelial cells. FEBS Lett, 580: 1565-1570

[150] Koga M, Murai J, Morita S, Saito H, Kasayama S (2013). Comparison of annual variability in HbA1c and glycated albumin in patients with type 1 vs. type 2 diabetes mellitus. Journal of diabetes and its complications, 27: 211-213

[151] Hayden MR, Tyagi SC (2002). Islet redox stress: the manifold toxicities of insulin resistance, metabolic syndrome and amylin derived islet amyloid in type 2 diabetes mellitus. JOP : Journal of the pancreas, 3 : 86-108

[152] Munoz A, Costa M (2013). Nutritionally mediated oxidative stress and inflammation. Oxid Med Cell Longev, 2013: 610950

[153] Gao L, Mann GE (2009). Vascular NAD(P)H oxidase activation in diabetes: a double-edged sword in redox signalling. Cardiovasc Res, 82: 9-20

[154] Zhang M, Kho AL, Anilkumar N, Chibber R, Pagano PJ, Shah AM, et al. (2006). Glycated proteins stimulate reactive oxygen species production in cardiac myocytes: involvement of Nox2 (gp91phox)containing NADPH oxidase. Circulation, 113: 12351243
[155] Newsholme P, Morgan D, Rebelato E, OliveiraEmilio HC, Procopio J, Curi R, et al. (2009). Insights into the critical role of NADPH oxidase(s) in the normal and dysregulated pancreatic beta cell. Diabetologia, 52: 2489-2498

[156] Koulajian K, Desai T, Liu GC, Ivovic A, Patterson JN, Tang C, et al. (2013). NADPH oxidase inhibition prevents beta cell dysfunction induced by prolonged elevation of oleate in rodents. Diabetologia, 56: 1078-1087

[157] Weaver JR, Grzesik W, Taylor-Fishwick DA (2015). Inhibition of NADPH oxidase-1 preserves beta cell function. Diabetologia, 58: 113-121

[158] Mira ML, Martinho F, Azevedo MS, Manso CF (1991). Oxidative inhibition of red blood cell ATPases by glyceraldehyde. Biochim Biophys Acta, 1060: 257-261

[159] Wolff SP, Dean RT (1987). Glucose autoxidation and protein modification. The potential role of 'autoxidative glycosylation' in diabetes. Biochem J, 245: 243-250

[160] Nishikawa T, Araki E (2013). Mechanism-based antioxidant therapies promise to prevent diabetic complications? Journal of diabetes investigation, 4: 105-107

[161] Wolff SP (1993). Diabetes mellitus and free radicals. Free radicals, transition metals and oxidative stress in the aetiology of diabetes mellitus and complications. Br Med Bull, 49: 642-652

[162] Tiganis $\mathrm{T}$ (2011). Reactive oxygen species and insulin resistance: the good, the bad and the ugly. Trends in pharmacological sciences, 32: 82-89

[163] Bocci V, Zanardi I, Huijberts MS, Travagli V (2014). An integrated medical treatment for type-2 diabetes. Diabetes \& metabolic syndrome, 8: 57-61

[164] Giacco F, Brownlee M (2010). Oxidative stress and diabetic complications. Circ Res, 107: 1058-1070

[165] Shaw A, Doherty MK, Mutch NJ, MacRury SM, Megson IL (2014). Endothelial cell oxidative stress in diabetes: a key driver of cardiovascular complications? Biochem Soc Trans, 42: 928-933

[166] Haldar SR, Chakrabarty A, Chowdhury S, Haldar A, Sengupta S, Bhattacharyya M (2015). Oxidative stress-related genes in type 2 diabetes: association analysis and their clinical impact. Biochem Genet, 53: 93-119

[167] Yan LJ (2009). Analysis of oxidative modification of proteins. Curr Protoc Protein Sci, Chapter 14: Unit14 14

[168] Ames BN, Shigenaga MK (1992). Oxidants are a major contributor to aging. Ann N Y Acad Sci, 663: 85-96

[169] Yan LJ, Sohal RS (1998). Mitochondrial adenine nucleotide translocase is modified oxidatively during aging. Proc Natl Acad Sci USA, 95: 12896-12901

[170] Yan LJ, Levine RL, Sohal RS (1997). Oxidative damage during aging targets mitochondrial aconitase. Proc. Natl. Acad. Sci. USA, 94: 11168-11172 
[171] Starkov AA (2008). The role of mitochondria in reactive oxygen species metabolism and signaling. Ann N Y Acad Sci, 1147: 37-52

[172] Lenaz G (2012). Mitochondria and reactive oxygen species. Which role in physiology and pathology? Adv Exp Med Biol, 942: 93-136

[173] Pollegioni L, Molla G (2011). New biotech applications from evolved D-amino acid oxidases. Trends Biotechnol, 29: 276-283

[174] Fang J, Sawa T, Akaike T, Maeda H (2002). Tumortargeted delivery of polyethylene glycol-conjugated D-amino acid oxidase for antitumor therapy via enzymatic generation of hydrogen peroxide. Cancer Res, 62: 3138-3143

[175] Haskew-Layton RE, Payappilly JB, Smirnova NA, Ma TC, Chan KK, Murphy TH, et al. (2010). Controlled enzymatic production of astrocytic hydrogen peroxide protects neurons from oxidative stress via an Nrf2-independent pathway. Proc Natl Acad Sci U S A, 107: 17385-17390

[176] Bando Y, Aki K (1991). Mechanisms of generation of oxygen radicals and reductive mobilization of ferritin iron by lipoamide dehydrogenase. J Biochem (Tokyo), 109: 450-454

[177] Sreider CM, Grinblat L, Stoppani AO (1990). Catalysis of nitrofuran redox-cycling and superoxide anion production by heart lipoamide dehydrogenase. Biochem Pharmacol, 40: 1849-1857

[178] Gazaryan IG, Krasnikov BF, Ashby GA, Thorneley RN, Kristal BS, Brown AM (2002). Zinc is a potent inhibitor of thiol oxidoreductase activity and stimulates reactive oxygen species production by lipoamide dehydrogenase. J Biol Chem, 277: 1006410072

[179] Tahara EB, Barros MH, Oliveira GA, Netto LE, Kowaltowski AJ (2007). Dihydrolipoyl dehydrogenase as a source of reactive oxygen species inhibited by caloric restriction and involved in Saccharomyces cerevisiae aging. Faseb J, 21: 274283

[180] Zhang Q, Zou P, Zhan H, Zhang M, Zhang L, Ge RS, et al. (2011). Dihydrolipoamide dehydrogenase and cAMP are associated with cadmium-mediated Leydig cell damage. Toxicol Lett, 205: 183-189

[181] Kareyeva AV, Grivennikova VG, Cecchini G, Vinogradov AD (2011). Molecular identification of the enzyme responsible for the mitochondrial NADH-supported ammonium-dependent hydrogen peroxide production. FEBS Lett, 585: 385-389

[182] Kareyeva AV, Grivennikova VG, Vinogradov AD (2012). Mitochondrial hydrogen peroxide production as determined by the pyridine nucleotide pool and its redox state. Biochim Biophys Acta,

[183] Quinlan CL, Goncalves RL, Hey-Mogensen M, Yadava N, Bunik VI, Brand MD (2014). The 2Oxoacid Dehydrogenase Complexes in Mitochondria Can Produce Superoxide/Hydrogen Peroxide at Much Higher Rates than Complex I. J Biol Chem,

[184] Tretter L, Adam-Vizi V (2005). Alpha-ketoglutarate dehydrogenase: a target and generator of oxidative stress. Philos Trans R Soc Lond B Biol Sci, 360: 2335-2345

[185] Starkov AA, Fiskum G, Chinopoulos C, Lorenzo BJ, Browne SE, Patel MS, et al. (2004). Mitochondrial alpha-ketoglutarate dehydrogenase complex generates reactive oxygen species. J Neurosci, 24: 7779-7788

[186] Ambrus A, Tretter L, Adam-Vizi V (2009). Inhibition of the alpha-ketoglutarate dehydrogenasemediated reactive oxygen species generation by lipoic acid. J Neurochem, 109 Suppl 1: 222-229

[187] Ambrus A, Torocsik B, Tretter L, Ozohanics O, Adam-Vizi V (2011). Stimulation of reactive oxygen species generation by disease-causing mutations of lipoamide dehydrogenase. Hum Mol Genet, 20: 2984-2995

[188] Manea A (2010). NADPH oxidase-derived reactive oxygen species: involvement in vascular physiology and pathology. Cell Tissue Res, 342: 325-339

[189] Bylund J, Brown KL, Movitz C, Dahlgren C, Karlsson A (2010). Intracellular generation of superoxide by the phagocyte NADPH oxidase: how, where, and what for? Free Radic Biol Med, 49: 18341845

[190] Harrison R (2004). Physiological roles of xanthine oxidoreductase. Drug Metab Rev, 36: 363-375

[191] Agarwal A, Banerjee A, Banerjee UC (2011). Xanthine oxidoreductase: a journey from purine metabolism to cardiovascular excitation-contraction coupling. Crit Rev Biotechnol, 31: 264-280

[192] Radi R (2013). Protein Tyrosine Nitration: Biochemical Mechanisms and Structural Basis of Functional Effects. Acc Chem Res, 46: 550-559

[193] Radi R, Cassina A, Hodara R, Quijano C, Castro L (2002). Peroxynitrite reactions and formation in mitochondria. Free Radic Biol Med, 33: 1451-1464

[194] Landino LM (2008). Protein thiol modification by peroxynitrite anion and nitric oxide donors. Methods Enzymol, 440: 95-109

[195] Singh IN, Sullivan PG, Hall ED (2007). Peroxynitrite-mediated oxidative damage to brain mitochondria: Protective effects of peroxynitrite scavengers. J Neurosci Res, 85: 2216-2223

[196] Alvarez B, Radi R (2003). Peroxynitrite reactivity with amino acids and proteins. Amino Acids, 25: 295-311

[197] Son SM (2012). Reactive oxygen and nitrogen species in pathogenesis of vascular complications of diabetes. Diabetes Metab J, 36: 190-198

[198] Stavniichuk R, Shevalye H, Lupachyk S, Obrosov A, Groves JT, Obrosova IG, et al. (2014). Peroxynitrite and protein nitration in the pathogenesis of diabetic peripheral neuropathy. Diabetes/metabolism research and reviews, 30: 669-678

[199] Hung LM, Huang JP, Liao JM, Yang MH, Li DE, Day YJ, et al. (2014). Insulin renders diabetic rats resistant to acute ischemic stroke by arresting nitric oxide reaction with superoxide to form peroxynitrite. J Biomed Sci, 21: 92 
[200] Li Y, Qi J, Liu K, Li B, Wang H, Jia J (2010). Peroxynitrite-induced nitration of cyclooxygenase-2 and inducible nitric oxide synthase promotes their binding in diabetic angiopathy. Mol Med, 16: 335342

[201] Liang JH, Li YN, Qi JS, Jia XX (2010). Peroxynitrite-induced protein nitration is responsible for renal mitochondrial damage in diabetic rat. $\mathrm{J}$ Endocrinol Invest, 33: 140-146

[202] Wu CH, Hsieh HT, Lin JA, Yen GC (2013). Alternanthera paronychioides protects pancreatic beta-cells from glucotoxicity by its antioxidant, antiapoptotic and insulin secretagogue actions. Food Chem, 139: 362-370

[203] Zhao WC, Zhang B, Liao MJ, Zhang WX, He WY, Wang HB, et al. (2014). Curcumin ameliorated diabetic neuropathy partially by inhibition of NADPH oxidase mediating oxidative stress in the spinal cord. Neurosci Lett, 560: 81-85

[204] Alam MM, Meerza D, Naseem I (2014). Protective effect of quercetin on hyperglycemia, oxidative stress and DNA damage in alloxan induced type 2 diabetic mice. Life Sci, 109: 8-14

[205] Niture NT, Ansari AA, Naik SR (2014). Antihyperglycemic activity of rutin in streptozotocininduced diabetic rats: an effect mediated through cytokines, antioxidants and lipid biomarkers. Indian journal of experimental biology, 52: 720-727

[206] Erejuwa OO, Sulaiman SA, Wahab MS, Sirajudeen KN, Salleh MS, Gurtu S (2010). Antioxidant protection of Malaysian tualang honey in pancreas of normal and streptozotocin-induced diabetic rats. Annales d'endocrinologie, 71: 291-296

[207] Parveen K, Khan MR, Mujeeb M, Siddiqui WA (2010). Protective effects of Pycnogenol on hyperglycemia-induced oxidative damage in the liver of type 2 diabetic rats. Chem Biol Interact, 186: 219227

[208] Ku CR, Lee HJ, Kim SK, Lee EY, Lee MK, Lee EJ (2012). Resveratrol prevents streptozotocin-induced diabetes by inhibiting the apoptosis of pancreatic beta-cell and the cleavage of poly (ADP-ribose) polymerase. Endocrine journal, 59: 103-109

[209] Chanpoo M, Petchpiboonthai H, Panyarachun B, Anupunpisit V (2010). Effect of curcumin in the amelioration of pancreatic islets in streptozotocininduced diabetic mice. Journal of the Medical Association of Thailand $=$ Chotmaihet thangphaet, 93 Suppl 6: S152-159

[210] Ding Y, Zhang Z, Dai X, Jiang Y, Bao L, Li Y, et al. (2013). Grape seed proanthocyanidins ameliorate pancreatic beta-cell dysfunction and death in lowdose streptozotocin- and high-carbohydrate/high-fat diet-induced diabetic rats partially by regulating endoplasmic reticulum stress. Nutrition \& metabolism, 10: 51

[211] Ola MS, Aleisa AM, Al-Rejaie SS, Abuohashish HM, Parmar MY, Alhomida AS, et al. (2014). Flavonoid, morin inhibits oxidative stress, inflammation and enhances neurotrophic support in the brain of streptozotocin-induced diabetic rats. Neurol Sci, 35: 1003-1008

[212] Hirst J, Carroll J, Fearnley IM, Shannon RJ, Walker JE (2003). The nuclear encoded subunits of complex I from bovine heart mitochondria. Biochim Biophys Acta, 1604: 135-150

[213] Carroll J, Fearnley IM, Skehel JM, Shannon RJ, Hirst J, Walker JE (2006). Bovine complex I is a complex of 45 different subunits. J Biol Chem, 281: 3272432727

[214] Carroll J, Ding S, Fearnley IM, Walker JE (2013). Post-translational modifications near the quinone binding site of mammalian complex I. J Biol Chem, 288: 24799-24808

[215] Andrews B, Carroll J, Ding S, Fearnley IM, Walker JE (2013). Assembly factors for the membrane arm of human complex I. Proc Natl Acad Sci U S A, 110: 18934-18939

[216] Hirst J (2013). Mitochondrial complex I. Annu Rev Biochem, 82: 551-575

[217] Murphy MP (2009). How mitochondria produce reactive oxygen species. Biochem J, 417: 1-13

[218] St-Pierre J, Buckingham JA, Roebuck SJ, Brand MD (2002). Topology of superoxide production from different sites in the mitochondrial electron transport chain. J Biol Chem, 277: 44784-44790

[219] Coughlan MT, Thorburn DR, Penfold SA, Laskowski A, Harcourt BE, Sourris KC, et al. (2009). RAGEinduced cytosolic ROS promote mitochondrial superoxide generation in diabetes. J Am Soc Nephrol, 20: 742-752

[220] Papa S, Sardanelli AM, Scacco S, Petruzzella V, Technikova-Dobrova Z, Vergari R, et al. (2002). The NADH: ubiquinone oxidoreductase (complex I) of the mammalian respiratory chain and the cAMP cascade. J Bioenerg Biomembr, 34: 1-10

[221] Hirst J, King MS, Pryde KR (2008). The production of reactive oxygen species by complex I. Biochem Soc Trans, 36: 976-980

[222] Bridges HR, Jones AJ, Pollak MN, Hirst J (2014). Effects of metformin and other biguanides on oxidative phosphorylation in mitochondria. Biochem J, 462: 475-487

[223] Fontaine E (2014). Metformin and respiratory chain complex I: the last piece of the puzzle? Biochem J, 463: e3-5

[224] Matsuzaki S, Humphries KM (2015). Selective inhibition of deactivated mitochondrial complex I by biguanides. Biochemistry, 54: 2011-2021

[225] Hur JH, Bahadorani S, Graniel J, Koehler CL, Ulgherait M, Rera M, et al. (2013). Increased longevity mediated by yeast NDI1 expression in Drosophila intestinal stem and progenitor cells. Aging, 5: 662-681

[226] Cho J, Hur JH, Graniel J, Benzer S, Walker DW (2012). Expression of yeast NDI1 rescues a Drosophila complex I assembly defect. PLoS One, 7: e50644

[227] Marella M, Seo BB, Nakamaru-Ogiso E, Greenamyre JT, Matsuno-Yagi A, Yagi T (2008). Protection by 
the NDI1 gene against neurodegeneration in a rotenone rat model of Parkinson's disease. PLoS One, 3: e1433

[228] Santidrian AF, Matsuno-Yagi A, Ritland M, Seo BB, LeBoeuf SE, Gay LJ, et al. (2013). Mitochondrial complex I activity and NAD+/NADH balance regulate breast cancer progression. J Clin Invest, 123: 1068-1081

[229] Luo X, Li R, Yan LJ (2015). Roles of Pyruvate, $\mathrm{NADH}$, and Mitochondrial Complex $\mathrm{I}$ in Redox Balance and Imbalance in $\beta$ Cell Function and Dysfunction. Journal of diabetes research,

[230] Brunmair B, Staniek K, Gras F, Scharf N, Althaym A, Clara R, et al. (2004). Thiazolidinediones, like metformin, inhibit respiratory complex I: a common mechanism contributing to their antidiabetic actions? Diabetes, 53: 1052-1059

[231] Sliwinska A, Drzewoski J (2015). Molecular Action of Metformin in Hepatocytes: an Updated Insight. Current diabetes reviews,

[232] Owen MR, Doran E, Halestrap AP (2000). Evidence that metformin exerts its anti-diabetic effects through inhibition of complex 1 of the mitochondrial respiratory chain. Biochem J, 348 Pt 3: 607-614

[233] Masini M, Anello M, Bugliani M, Marselli L, Filipponi F, Boggi U, et al. (2014). Prevention by metformin of alterations induced by chronic exposure to high glucose in human islet beta cells is associated with preserved ATP/ADP ratio. Diabetes research and clinical practice, 104: 163-170

[234] Viollet B, Guigas B, Sanz Garcia N, Leclerc J, Foretz M, Andreelli F (2012). Cellular and molecular mechanisms of metformin: an overview. Clin Sci (Lond), 122: 253-270

[235] Pernicova I, Korbonits M (2014). Metformin--mode of action and clinical implications for diabetes and cancer. Nature reviews. Endocrinology, 10: 143-156

[236] Jenkins Y, Sun TQ, Markovtsov V, Foretz M, Li W, Nguyen H, et al. (2013). AMPK activation through mitochondrial regulation results in increased substrate oxidation and improved metabolic parameters in models of diabetes. PLoS One, 8: e81870

[237] Hinke SA, Martens GA, Cai Y, Finsi J, Heimberg H, Pipeleers D, et al. (2007). Methyl succinate antagonises biguanide-induced AMPK-activation and death of pancreatic beta-cells through restoration of mitochondrial electron transfer. Br J Pharmacol, 150: 1031-1043

[238] Hopson NE, Sack WA (1973). Cellular phosphorus changes under low-carbon stress. J Water Pollut Control Fed, 45: 85-96

[239] Kosanam H, Thai K, Zhang Y, Advani A, Connelly KA, Diamandis EP, et al. (2014). Diabetes induces lysine acetylation of intermediary metabolism enzymes in the kidney. Diabetes, 63: 2432-2439

[240] Frizzell N, Thomas SA, Carson JA, Baynes JW (2012). Mitochondrial stress causes increased succination of proteins in adipocytes in response to glucotoxicity. Biochem J, 445: 247-254
[241] Fritz KS, Galligan JJ, Hirschey MD, Verdin E, Petersen DR (2012). Mitochondrial acetylome analysis in a mouse model of alcohol-induced liver injury utilizing SIRT3 knockout mice. J Proteome Res, 11: 1633-1643

[242] Fritz KS, Green MF, Petersen DR, Hirschey MD (2013). Ethanol metabolism modifies hepatic protein acylation in mice. PLoS One, 8: e75868

[243] Verdin E, Ott M (2015). 50 years of protein acetylation: from gene regulation to epigenetics, metabolism and beyond. Nature reviews. Molecular cell biology, 16: 258-264

[244] Cohn RM, Roth KS (1996) Biochemistry and diabetes, Williams \& Wilkins, Baltimore

[245] Paik WK, Pearson D, Lee HW, Kim S (1970). Nonenzymatic acetylation of histones with acetylCoA. Biochim Biophys Acta, 213: 513-522

[246] Ramponi G, Manao G, Camici G (1975). Nonenzymatic acetylation of histones with acetyl phosphate and acetyl adenylate. Biochemistry, 14: 2681-2685

[247] Baeza J, Smallegan MJ, Denu JM (2015). Sitespecific reactivity of nonenzymatic lysine acetylation. ACS Chem Biol, 10: 122-128

[248] Wagner GR, Payne RM (2013). Widespread and enzyme-independent Nepsilon-acetylation and Nepsilon-succinylation of proteins in the chemical conditions of the mitochondrial matrix. J Biol Chem, 288: 29036-29045

[249] Muoio DM (2014). Metabolic inflexibility: when mitochondrial indecision leads to metabolic gridlock. Cell, 159: 1253-1262

[250] Morris BJ (2013). Seven sirtuins for seven deadly diseases of aging. Free Radic Biol Med, 56: 133-171

[251] Caton PW, Richardson SJ, Kieswich J, Bugliani M, Holland ML, Marchetti P, et al. (2013). Sirtuin 3 regulates mouse pancreatic beta cell function and is suppressed in pancreatic islets isolated from human type 2 diabetic patients. Diabetologia, 56: 1068-1077

[252] Michan S (2014). Calorie restriction and $\mathrm{NAD}(+) /$ sirtuin counteract the hallmarks of aging. Front Biosci (Landmark Ed), 19: 1300-1319

[253] Yang T, Sauve AA (2006). NAD metabolism and sirtuins: metabolic regulation of protein deacetylation in stress and toxicity. AAPS J, 8: E632-E643

[254] Wang Y (2014). Molecular Links between Caloric Restriction and Sir2/SIRT1 Activation. Diabetes Metab J, 38: 321-329

[255] Ramis MR, Esteban S, Miralles A, Tan DX, Reiter RJ (2015). Caloric restriction, resveratrol and melatonin: Role of SIRT1 and implications for aging and related-diseases. Mech Ageing Dev, 146-148C: $28-41$

[256] Kincaid B, Bossy-Wetzel E (2013). Forever young: SIRT3 a shield against mitochondrial meltdown, aging, and neurodegeneration. Front Aging Neurosci, 5: 48

[257] Canto C, Gerhart-Hines Z, Feige JN, Lagouge M, Noriega L, Milne JC, et al. (2009). AMPK regulates energy expenditure by modulating NAD+ 
metabolism and SIRT1 activity. Nature, 458: 10561060

[258] Kim HJ, Kim JH, Noh S, Hur HJ, Sung MJ, Hwang JT, et al. (2011). Metabolomic analysis of livers and serum from high-fat diet induced obese mice. J Proteome Res, 10: 722-731

[259] Jing E, Emanuelli B, Hirschey MD, Boucher J, Lee KY, Lombard D, et al. (2011). Sirtuin-3 (Sirt3) regulates skeletal muscle metabolism and insulin signaling via altered mitochondrial oxidation and reactive oxygen species production. Proc Natl Acad Sci U S A, 108: 14608-14613

[260] Hirschey MD, Shimazu T, Jing E, Grueter CA, Collins AM, Aouizerat B, et al. (2011). SIRT3 deficiency and mitochondrial protein hyperacetylation accelerate the development of the metabolic syndrome. Mol Cell, 44: 177-190

[261] Wang RH, Kim HS, Xiao C, Xu X, Gavrilova O, Deng CX (2011). Hepatic Sirt1 deficiency in mice impairs mTorc2/Akt signaling and results in hyperglycemia, oxidative damage, and insulin resistance. J Clin Invest, 121: 4477-4490

[262] Cerutti R, Pirinen E, Lamperti C, Marchet S, Sauve AA, Li W, et al. (2014). NAD(+)-dependent activation of Sirt1 corrects the phenotype in a mouse model of mitochondrial disease. Cell Metab, 19: 1042-1049

[263] Balestrieri ML, Rizzo MR, Barbieri M, Paolisso P, D'Onofrio N, Giovane A, et al. (2015). Sirtuin 6 expression and inflammatory activity in diabetic atherosclerotic plaques: effects of incretin treatment. Diabetes, 64: 1395-1406

[264] de Kreutzenberg SV, Ceolotto G, Papparella I, Bortoluzzi A, Semplicini A, Dalla Man C, et al. (2010). Downregulation of the longevity-associated protein sirtuin 1 in insulin resistance and metabolic syndrome: potential biochemical mechanisms. Diabetes, 59: 1006-1015

[265] Hou X, Zeng H, He X, Chen JX (2015). Sirt3 is essential for apelin-induced angiogenesis in postmyocardial infarction of diabetes. J Cell Mol Med, 19: 53-61

[266] Herskovits AZ, Guarente L (2013). Sirtuin deacetylases in neurodegenerative diseases of aging. Cell Res, 23: 746-758

[267] Turkmen K, Karagoz A, Kucuk A (2014). Sirtuins as novel players in the pathogenesis of diabetes mellitus. World J Diabetes, 5: 894-900

[268] Hassa PO, Haenni SS, Elser M, Hottiger MO (2006). Nuclear ADP-ribosylation reactions in mammalian cells: where are we today and where are we going? Microbiol Mol Biol Rev, 70: 789-829

[269] Kaelin WG, Jr., McKnight SL (2013). Influence of metabolism on epigenetics and disease. Cell, 153: 5669

[270] Mouchiroud L, Houtkooper RH, Auwerx J (2013). $\mathrm{NAD}(+)$ metabolism: a therapeutic target for agerelated metabolic disease. Critical reviews in biochemistry and molecular biology, 48: 397-408
[271] Huynh FK, Hershberger KA, Hirschey MD (2013). Targeting sirtuins for the treatment of diabetes. Diabetes Manag (Lond), 3: 245-257

[272] Kitada M, Kume S, Kanasaki K, Takeda-Watanabe A, Koya D (2013). Sirtuins as possible drug targets in type 2 diabetes. Curr Drug Targets, 14: 622-636

[273] Lin H, Su X, He B (2012). Protein lysine acylation and cysteine succination by intermediates of energy metabolism. ACS Chem Biol, 7: 947-960

[274] Piroli GG, Manuel AM, Walla MD, Jepson MJ, Brock JW, Rajesh MP, et al. (2014). Identification of protein succination as a novel modification of tubulin. Biochem J, 462: 231-245

[275] Merkley ED, Metz TO, Smith RD, Baynes JW, Frizzell N (2014). The succinated proteome. Mass Spectrom Rev, 33: 98-109

[276] Yang M, Ternette N, Su H, Dabiri R, Kessler BM, Adam J, et al. (2014). The Succinated Proteome of FH-Mutant Tumours. Metabolites, 4: 640-654

[277] Blatnik M, Thorpe SR, Baynes JW (2008). Succination of proteins by fumarate: mechanism of inactivation of glyceraldehyde-3-phosphate dehydrogenase in diabetes. Ann N Y Acad Sci, 1126: 272-275

[278] Nagai R, Brock JW, Blatnik M, Baatz JE, Bethard J, Walla MD, et al. (2007). Succination of protein thiols during adipocyte maturation: a biomarker of mitochondrial stress. J Biol Chem, 282: 34219-34228

[279] Zheng L, Cardaci S, Jerby L, MacKenzie ED, Sciacovelli M, Johnson TI, et al. (2015). Fumarate induces redox-dependent senescence by modifying glutathione metabolism. Nat Commun, 6: 6001

[280] Yan LJ (2014). Positive oxidative stress in aging and aging-related disease tolerance. Redox Biology, 2: 165-169

[281] Yan LJ (2014). Protein Redox Modification as a Cellular Defense Mechanism against Tissue Ischemic Injury. Oxidative Medicine and Cellular Longevity, 2014: 12

[282] Winterbourn CC, Hampton MB (2008). Thiol chemistry and specificity in redox signaling. Free Radic Biol Med, 45: 549-561

[283] Ying J, Clavreul N, Sethuraman M, Adachi T, Cohen RA (2007). Thiol oxidation in signaling and response to stress: detection and quantification of physiological and pathophysiological thiol modifications. Free Radic Biol Med, 43: 1099-1108

[284] Forman HJ, Fukuto JM, Torres M (2004). Redox signaling: thiol chemistry defines which reactive oxygen and nitrogen species can act as second messengers. Am J Physiol Cell Physiol, 287: C246256

[285] Fomenko DE, Marino SM, Gladyshev VN (2008). Functional diversity of cysteine residues in proteins and unique features of catalytic redox-active cysteines in thiol oxidoreductases. Molecules and cells, 26: 228-235

[286] Biswas S, Chida AS, Rahman I (2006). Redox modifications of protein-thiols: emerging roles in cell signaling. Biochem Pharmacol, 71: 551-564 
[287] Cai Z, Yan LJ (2013). Protein oxidative modifications: Beneficial roles in disease and health. Journal of Biochemical and Pharmacological Research, 1: 15-26

[288] White H, Venkatesh B (2011). Clinical review: ketones and brain injury. Crit Care, 15: 219
[289] Cotter DG, Schugar RC, Crawford PA (2013). Ketone body metabolism and cardiovascular disease. Am J Physiol Heart Circ Physiol, 304: H1060-1076 